\title{
3 Forests of Learning and the Invention of Religious Traditions
}

A series of important political developments took place in the Deccan region in the fourteenth century, with which the evolution of sainthood and its ideology in the coming centuries was deeply interlaced. It had a long history. An overview of this history will be instructive, as it will enable us to place the subsequent discussions in a fruitful perspective.

The Cāḷkyas of Kalyāna (ca. 973-1200) were in control of large parts of the Deccan region in the eleventh and the twelfth centuries. ${ }^{127}$ When their power began to decline in the mid twelfth century, the Kaḷacūris of Mañgalavāḍa (now Mañgalvēọhā) began to assert themselves. The Kalacūri chief Permāḍi had earlier entered into a matrimonial alliance with the Cālukyas, which had enabled his family to exercise greater influence in the affairs of the state. The agrarian infrastructure that he commanded from his headquarters at Mañgalavāda on the riparian belt of the Bhima was among the most formidable in the region. His son, Bijjala II, began to assert his independence in the wake of a conflict over succession between Sōmēśvara III's sons, Jagadēkamalla II and Mallikārjuna. Under Jagadēkamalla II’s successor Taila III, the Cāḷukyan forces suffered serious setbacks following attacks from the Kākatīya chief, Prōla. Taking advantage of this situation, Bijjala II usurped the throne in 1162. Taila III tried to retain a foothold, but was killed by his Hoysala subordinate, Narasiṃha I (r. ca. 1152-1173), perhaps in 1163. Bijjala II's was not a successful entreprise, though. His rule came to an end in 1167 following what seems to have been a case of regicide. The killer, whom legends identify as Jagadēva, was apparently faithful to the Cālukyas, and continued to espouse their cause, if evidence from epigraphy is to be believed. Owing to the fact that Bijjala II's relationship with his treasurer Basava had turned into friction towards the end of his life, later Viraśaiva accounts have appropriated Jagadēva's act by identifying him as a devotee of Basava. In subsequent accounts, the killing was jointly attributed to Jagadēva and Mallibomma, both allegedly Basava's followers. Bijjala II was succeeded by his son Sōvidēva who ruled up to 1176. What followed was sheer confusion. Between the years 1176 and 1184, the throne was occupied by at least five rulers, Mailugi, Sañkama, Āhavamalla, Kannara, and Singhaṇa. ${ }^{128}$ The Cālukyas returned to power briefly under Sōmēśvara IV, but by this time, their realm had come to be parceled out between three prominent warlord families, the Sēvunas of Dēvagiri, the Kākatīyas of Vāranigallu, and the Hoysaḷas of Dōrasamudraṃ (Haḷēbị̣u), who carved out spheres of influences in the Marathi, Telugu, and Kannada speaking regions, respectively. They represented the great dryland polities, which contrasted in

127 For a history of the Kalyāṇa Cālukyas, see Gopal 1981.

128 On the Kalacūris, see Desai 1968. Also, Gopal 1981. 
many ways with the Cōlas of Tañjāvūr, the Cēras of Mahōdayapuraṃ, and the eastern Cālukya chiefs of Vengi, who were rooted in wetland regions, although their sway extended over dryland belts as well. By the early decades of the fourteenth century, these successor states had also weakened considerably.

Between the ninth and the thirteenth centuries, powerful peasant proprietors and warlords had been enlisted into the service of the state across much of peninsular India in various capacities, but mostly as revenue farmers commanding militias of their own. Wetland polities also appropriated mercantile groups for extracting revenue. This was most prominently seen among the Cōlas ${ }^{129}$ and, to a lesser extent, among the Cēras. ${ }^{130}$ According to Kesavan Veluthat, the corporate body of merchants, called nagaram, "is shown to have been held collectively responsible for the collection of land revenues from its domain and to have handled its internal assessments and collections in a manner as it saw fit". ${ }^{131}$ Kenneth R. Hall identifies the nagaram as an administrative institution, ${ }^{132}$ stresses its role in collecting revenue on behalf of the Cōla state, ${ }^{133}$ and notes that its "right to tax was distinct from its private right over land". ${ }^{134}$ But merchants did not figure in a similar capacity in the dryland polities. In fact, the data made available by inscriptions show that some of these states shared a difficult relationship with the powerful merchant syndicates of the day. The Cannakēśava temple of Belūru, built in the early twelfth century by the Hoysala king Vișnuvardhana, received grants, gifts, and donations from a number of people. Not one of them was a merchant before the fifteenth century. ${ }^{135}$ At Śravanabelagola, merchants were more active on the big hill, whereas their presence was almost negligible on the small hill, where functionaries of the Hoysala state dominated. ${ }^{136}$ Hoysala relationship with the mercantile classes was anything but cordial.

In the dryland belts of southern Karnataka, peasant proprietors who gained greater access to state revenue succeeded in the course of the eleventh, the twelfth, and the thirteenth centuries in developing and controlling rural markets. A certain Ādigavunḍa obtained control of a (weekly?) fair and, with the help of his brothers and

129 Hall 1980.

130 The Syrian Christian (Tarisāpaḷli) copperplates and the Jewish copperplates exemplify this. For the text of the Jewish copperplates, see No. 39, Ramachandran 2007. It was believed for a long time that there were two sets of Syrian Christian copperplates, recording two different grants. M.R. Raghavavarier and Kesavan Veluthat have recently shown that the so-called second set of plates is only a continuation of the first set. In effect, therefore, there is only one set of plates. See Raghavavarier and Veluthat 2013 for a revised text and a reassessment of the plates.

131 Veluthat 2012: 220.

132 Hall 1980: 51-63 (i.e., chapter 3).

133 Ibid., 58-59, passim.

134 Ibid., 62.

135 Cf. Bl. 1-93, Epigraphia Carnatica, (revised edition), Vol. 9.

136 Cf. inscriptions in Epigraphia Carnatica, (second revised edition), Vol. 2. 
sons, built a village from its proceeds in 1182, after clearing the forests. ${ }^{137}$ An earlier case of obtaining the revenue of a fair comes from Tekkalakōte in the Baḷāri district from the year $1020 .{ }^{138}$ Peasant proprietors were beginning to gain a firm foothold over rural markets in the south and in the Tungabhadra valley. Inscriptions from this period mention a large number of merchants, i.e., setțis, in southern Karnataka, which, one might argue, goes against our proposition that peasant magnates controlled the rural markets. But there is evidence to show that these merchants belonged to peasant proprietor families. An inscription from the time of Ballāla II speaks of a Sețtigauṇda. That he was a peasant magnate is underscored by the expression gaunda (originally gāvuṇda from the Sanskrit grāmavrddha, now gauda). But he had sețti, 'trader', as a personal name. His two sons swore allegiance to the king, which is indicated by the stock expression, tatpādapadmōpajīivi, 'who lives by that lotus feet'. One of them, Taḷāra Sunkada Mahadēvaṇna, controlled the transit toll on the movement of goods (sunkka). The other, Būciya Boppasețti, was a merchant. Mahadevaṇna’s son-in-law was Kētamalla Heggaḍe, and as his title suggests, he maintained village records. Elsewhere, he is referred to as Talāana Sunkada Kētamalla, suggesting that he inherited the rights to transit toll from his father-in-law. ${ }^{139}$ Until recent times, Settigauda was a common name in the Hāsana district and adjoining areas of southern Karnataka. A thirteenth century inscription from Sōmavārapēte in Koḍagu district refers to several peasant proprietors (gaudugalu) as constituting the nādu-nakhara. ${ }^{140}$ This compound expression is revealing: $n \bar{a} d u$ (Sanskrit vișaya) is a peasant locality, ${ }^{141}$ and nakhara, the corporate body of local merchants. A group of peasant proprietors, who managed the agrarian affairs of a locality, were also in control of its mercantile initiatives.

By the twelfth century, individual merchants had emerged in southern as well as northern Karnataka, who operated in their own capacity without being aligned to any of the great merchant syndicates. This was the outcome of a historically far-reaching development that took place after the tenth century, and which has for some reason continued to elude the historian's gaze, viz., the practice of making gift of money or gold as endowment to temples and religious establishment in lieu of land grant, by the merchant syndicates. This birth of interest-bearing capital gradually percolated into the realms of agrarian production in the form of usury. The potentials that credit was imbued with led to individual mercantile and moneylending initiatives. Ādayya, with whose story we commenced this study, was one such merchant. Pārisasetți, the father of Padmāvati whom Ādayya married, was another. Neither of them was affiliated to

137 Bl. 240, Epigraphia Carnatica, (revised edition), Vol. 9.

138 Siraguppa 55, Kannada University Epigraphical Series, Vol. 1. Tekkalakōṭe was among the most prominent of neolithic settlements in the Deccan region.

139 Bl. 373, Epigraphia Carnatica, (revised edition), Vol. 9.

140 No. 60, Epigraphia Carnatica, (revised edition), Vol. 1.

141 On the nādus of Tamilnadu, see Subbarayalu 1973 and Veluthat 1990. Adiga 2006 offers a discussion in the context of Karnataka. Also see Ganesh 2010 for nādus in Kerala. 
any merchant syndicate of the day. The growing power on the one hand of peasant proprietors and the supralocal alliances they were successful in forging, and on the other of the individual merchants who began to develop systems of agrarian credit, led to the decline of organized mercantile groups. Great syndicates of the preceding centuries such as the Ayyāvole Ainūrvar or the Diśai Āyiratti Aiññūrruvar, the Maṇigrāmaṃ, the Hañjamāna (Anjuman?), the Valañjiyar, and many itinerant groups called Nānādēśi, withered away, as did local merchant groups like the nakharas or the nagarams. ${ }^{142}$ By the late thirteenth century, their presence had become too feeble to be recorded, and by the close of the fifteenth century, the last of the nakharas and the Hañjamānas, who unlike the other groups seem to have resisted dissolution, had also vanished from the scene completely.

The major peasant magnates were also in control of military bands that were placed at the service of the state as and when called upon to do so. With the increasing autonomy of the market-controlling peasant proprietors, it became possible for rival powers to buy their loyalties. The individual merchant represented a centrifugal tendency that was hard for the state to contain. This was all the more so because, the northern peasantry was gradually coming under the spell of the private moneylender, and was serving his cause at the expense of the services it hitherto rendered as mercenary troops to the state and its functionaries. This situation of precarious loyalties weakened the Sēvuṇas, the Kākatīyas, and the Hoysalas to a considerable extent. Beginning 1296, a series of invasions by the Khalji and the Tughlak Saltanats of Dilli laid bare the vulnerability of these states.

Alā-ud-dīn Khalji was the first of the Sultāns of Dilli to raid the Deccan. As early as 1293, when his uncle Jalāl-ud-dīn Khalji held the throne, he carried out a campaign in central India around the areas centering on Bhilsa. In 1296, he invaded Dēvagiri without the Sultān's knowledge, defeated the Sēvuṇa king Rāmacandra, and returned with rich booty. The Sultān was assassinated shortly thereafter, on 21 July 1296, and Alā-ud-dīn enthroned. In the first few years of his reign, Alā-ud-dīn was engaged in consolidating his hold over north India. He ordered a campaign against Vārañgallu in 1302, but his forces were defeated by the fierce troops of the Kākatīya king, Pratāparudra II, in 1303. Three years later, in 1306, he ordered a campaign against Dēvagiri. Alāud-dīn's trusted eunuch general, Malik Kāfūr, led this campaign, and returned after reducing Rāmacandra to submission. Malik was sent again to the south late in 1309. With Rāmacandra offering military assistance, Malik came to command a formidable army. Rāmacandra died shortly thereafter. Malik's campaign was extensive. It lasted

142 The Ayyāvole 500 and Manigrāmam syndicates are discussed at length in Abraham 1988. Also see Hall 1980; Champakalakshmi 1996: 311-326 (i.e., chapter 5); Veluthat 2012: 218-222. The Hañjamāna was active in coastal Karnataka even in the late fourteenth century (No. 350, South Indian Inscriptions, Vol. 7, record dated 1399) and the early fifteenth century (No. 349, South Indian Inscriptions, Vol. 7, record dated 1406), but vanished by the end of the fifteenth century. 
up to 1311. Malik reduced Vārangallu with the help of the deceased Rāmacandra's forces, and coerced Pratāparudra II to acquiesce. The Hoysala king Ballāla III, and the Pāṇdyan brothers of Madurai, Sundara Pāṇḍan and Vĩra Pāṇḍan, were defeated and forced to sue for peace. These victories were made possible due to the support Malik Kāfūr was able to marshal from Pratāparudra II. ${ }^{143}$ Two years later, in 1313, he marched again against Dēvagiri to rein in Rāmacandra's son and successor, Singhana III, who was hostile to Dilli. Alā-ud-din died on the fourth day of the year 1316. Half and three months later and after a number of intrigues, his son Mubārak ascended throne on 18 April. Three years later, in 1319, he attacked Dēvagiri. It was Mubārak who for the first time commissioned governors in his conquered territory in the Deccan, thereby departing from Alā-ud-dīn's policy of subjugation for tribute. Yaklakhī was appointed the governor of Dēvagiri, which brought an end to the Sēvuna state. Mubarak had similar plans to annex the Kākatīya region. He asked his trusted homosexual partner Hassan, upon whom he had conferred the title of Khusrau Khān, to invade Vārañgallu. Khusrau Khān was an influential figure in the early fourteenthcentury politics of Dilli. He succeeded in killing Mubārak in 1320, and rose to the throne as Nāsir-ud-dīn. But Khusrau's rule lasted only for two months. He was killed by his opponent Ghāzi Malik, who held Dīpālpur at the time. Ghāzi Malik succeeded Khusrau to the Dilli throne as Ghiyās-ud-dīn Tughlak. Thus commenced the Tughlak rule.

In the following year, 1321, Ghiyās sent his son Fakhr-ud-Dīn Jauna, who now carried the title Ulugh Khān, to invade Vārangallu and collect tributes. Jauna had other plans. Instead of reducing Vārangallu to a tributary status, he wished to annex it to Dilli. But the campaign turned out to be a disaster. Two years later, in 1323, Jauna invaded Vārańgallu again. This time around, he succeeded in annexing it. Vāraṅgallu was renamed Sultānpur, the Svayambhu Śiva temple of the city razed, a mosque built in the vicinity of the old temple, and a mint established to utter Tughlak coins. ${ }^{144}$ A century and a half of Kākatìya rule was thus brought to an end. Ghiyās died in 1325. Jauna succeeded him, adopting the name Muhammad bin Tughlak. Muhammad aspired to bring much of the Deccan under Dilli's control, and evolved a number of strategies to this effect. The first of these was to appoint governors in the region. This turned out to be an unsuccessful measure after his cousin Bahā-ud-dīn Gurśāsp, the governor of Sagara, rebelled against him in 1326. Soon thereafter, in 1327, Muhammad decided to move the capital of the Saltanat from Dilli to Dēvagiri in order to contain recalcitrant tendencies among the governors. In 1328, he ordered the people of Dilli to move to the new capital, which was renamed Daulatābād. The project turned out to be a disaster. Thousands died during the journey. Most migrants returned back to Dilli by 1335. Jalāl-ud-dīn Ahsān Khān, the Tughlak governor of Madurai, declared

143 Talbot 2001: 135.

144 Eaton 2005: 20-21. 
his independence and founded the Saltanat of Madurai in 1335. Muhammad's control over the Deccan became tenuous in the coming years, and when he died on 20 March 1351, the region was effectively out of Dilli's reach.

Among the numerous acts of insubordination that led to the collapse of Dilli's authority in the Deccan, two were especially significant. The first of these came from a recalcitrant Tughlak military official, Hassan Gangu, who held the title Zafar Khān. He occupied Daulatābad, and declared his independence in 1345. Hassan assumed a regal name, Alā-ud-dīn Hassan Bahman Śāh. In 1347, he moved to Kalaburagi, ${ }^{145}$ where the wheels of the Bahmani state were fully set in motion. The second act was less rebellious in nature. It came from Harihara I, Bukka I, Kampaṇa I, Muddappa, and Mārappa, the five sons of a certain Sangama. They had served their political apprentice under the Hoysalas. ${ }^{146}$ The Hoysala state had weakened to a great extent following repeated raids from Dilli, but its territory was still not lost. Unlike Dēvagiri, Vārangallu, and Madurai, which were placed under governors after overthrowing the Sēvuna, the Kākatīya, and the Pāṇdya states, respectively, Dilli had not succeeded in eliminating the Hoysalas. The Sangama brothers were thus able to take advantage of the vacuum created by the decline in Hoysala influence, without engaging in confrontation with Dilli. Harihara I seems to have commenced his independent rule in or shortly before 1346, an act that is likely to have been inspired by Hassan Gangu's defiance of Dilli a year ago. In his early years, he ruled from the Hoysala heartland. By the late 1350s, he had consolidated his position around Hampi, known variously at the time as Hosapaț̣aṇa, Vijayavirūpākșapura, and Virūpākṣapaț̣aṇa, and since 1357, as Vijayanagara. The great initiative that commenced with Harihara I and his four brothers was to have a lasting impression on the praxis of statecraft in the region.

Like their immediate predecessors, both the Vijayanagara and the Bahmani states were dryland polities. Burton Stein has gone to the extent of saying that "Vijayanagara was to prove the grand apotheosis" of dryland political formations. ${ }^{147}$ But contrary to Stein's view, the Vijayanagara kings were also in control of the riparian belts, ${ }^{148}$ as irrigation in the Vijayanagara heartland was mainly tank-fed, and had to depend upon the great tank watershed networks replenished through thousands of channels drawn from the perennial rivers. Under this geopolitical dispensation, peasant proprietors constituted the most dominant class that controlled the economy of the region.

145 Gulbarga, as renamed by the Government of Karnataka in 2014.

146 This is confirmed by contemporary inscriptions, although literary sources from a later date at times speak of the Sangamas as serving the Kākatīyas. See Kulke 1993: $208-239$ (i.e., chapter 11) for a discussion.

147 Stein 1989: 21.

148 Ibid. 
There were intrinsic differences in the economy controlled by the Bahmanis and the Vijayanagara rulers. The Bahmanis held sway over the areas to the north of the Kṛnna, and oftentimes, to the north of the Tungabhadra. The Vijayanagara rule on the other hand was concentrated to the south of these rivers. The north was a blacksoil belt, parts of which fell within the basaltic Deccan trap. There were considerable stretches of plains too, although the general alignment of the land was towards the east. The plains, and their great rivers like the Gōdāvari, the Bhīma, the Kṛ̣ṇa, and the Malaprabha, played key roles in the evolution of the peasantry in this region. As early as the first and second centuries CE, the north was able to support petty chiefdoms and impressive Buddhist establishments like the ones found in Sannati and VadagāvMādhavapura (Belagāvi). It was in this region that the most important states of the Deccan, like the Bādāmi Calukyas, the Rāṣțrakūṭas, and the Kalyāṇa Cāḷkukyas, arose. In sharp contrast, the south had an undulating topography. Lowlands merged into the plains, hills skirted the lowlands, fertile pieces of land lie scattered in the midst of granite outcrops. Agriculture was extensively dependent on tank irrigation. The production of grain surplus was less impressive, compared to the north. As a result, an entrenched class of peasantry was slow to emerge in the areas to the south of the Tungabhadra. Few attempts were made to establish states here. Fewer were actually successful.

One consequence of this difference was that the modes of surplus extraction between the north and the south were substantially different from each other. In the north, peasant localities called nā $d u$ were larger in size, fewer in number, and managed more effectively through assessments and extraction of taxes and rents by locality chiefs and peasant proprietors, who worked closely with the state. Unlike the Cōla heartland, where the countless distributaries of the Kāvēri, a perennial river, enabled the development of extensive tank watersheds and the parcelling of agrarian land among numerous claimants due to the availability of irrigation water in spite of poor monsoon rains, which in turn paved way for the rise of hundreds of nādus, the dryland belts to the north of the Tungabhadra and the Kṛṣna suffered from want of irrigation. The general eastward tilt of the land made the construction of tank networks difficult, and at times, impossible. As a result, tanks were built less frequently in the north. Incentives from smaller holdings were therefore less attractive, although the fertility of the soil was impressive. Consequently, holdings tended to be huge. As opposed to this, nādus flourished in the south even when state control was tenuous. This was because in the absence of extensive plain-land, small pieces of land were upturned for cultivation. These were under the control of local peasant magnates. Scarcity-both potential and real-forced the peasantry into raids and brigandage. This is testified by the hundreds of hero-stones found in the south, recording the death of 'heroes' in cattle-lifting adventures. Under these geographical constraints, large holdings were not easily forthcoming. The number of $n \bar{a}$ dus was therefore greater in the south, and their size, smaller. And owing to the unevenness of the terrain, which threw up numerous natural depressions and made the eastward 
tilt of the land less prominent, it was possible to build tanks in great numbers. Correspondingly, and in consequence, the number of peasant proprietors was also larger. This made systematic assessments and collection of revenue a tricky affair for the state. The ideal solution to the problem was to establish tributary relationships with the big men of the localities.

The invaders from Dilli seem to have clearly understood this difference between the north and the south. In a recent study, Richard M. Eaton and Phillip B. Wagoner have observed that the Tughlaks assigned $i k t a \bar{s}$ or revenue assignments to the erstwhile chiefs under the Sēvuṇas and the Kākatīyas to the north of the Kụṣna. The iktādārs turned into instruments of regular tax collection in these areas. To the south, however, the autonomy of the former chiefs was recognized. These chiefs were identified as amirs. They paid tributes to the Tughlak state. ${ }^{149}$ Thus, the agrarian structure-which depended upon the geography of the region-determined the nature of surplus appropriation in the Deccan. The Bahmani state spread out its reach over the areas where the Tughlaks had established iktādāri. The authority of the Vijayanagara state extended over the landscape of the amirs. This distinction is crucial for the purposes of our study.

Very early in their existence, the Vijayanagara kings forged an alliance with the mațha of Śrngēri. There is a popular legend, often presented as history, which attributes the founding of the Vijayanagara state to Vidyāranya, the pontiff of the Śrngēri mațha. This, nevertheless, is not borne out by contemporary evidence. It is a story promoted by the Śrngēri matha only in the sixteenth century when the Sangama state, which supported them, was not in existence any more, and the Tuluva rulers, who swore by Vaișnavism, promoted the cause of the Venkkațêsvara temple of Tirupati. ${ }^{150}$ According to Joan-Pau Rubiés, the Vidyāranyya legend was meant to provide dharmic legitimation to the new dynasty. ${ }^{151}$ Although the legend was from a later date, the relationship between the matha and the Sangama brothers was not. As early as 1346, the five brothers celebrated a vijayōtsava at Śrngēeri, during which Harihara I granted nine villages to the pontiff, Bhāratī Tīrtha. ${ }^{152}$ Ten years later, in 1356, Bukka I visited Śrngēeri, and made an endowment to Vidyā Tīrtha. ${ }^{153}$ It was in 1375 that Vidyāranya received a grant. ${ }^{154} \mathrm{He}$ was the pontiff at the time. Considering the fact that Bhāratī Tīrtha died in 1374, it is reasonable to suggest that Vidyāraṇya rose to become pontiff that year. The role he played in making the Śrngēri mața an

149 Eaton and Wagoner 2014: 27.

150 Kulke 1993: 212-213.

151 Rubiés 2000: 262. It is, however, not clear why the early founders of Vijayanagara did not resort to seek 'legitimacy' through such legends. The theory of legitimacy has been called into question in recent years. See Pollock 2007: 511-524.

152 Kulke 1993: 226-227.

153 Ibid., p. 227.

154 Ibid. 
influential establishment was seminal, as was his role in advancing the cause of a new vaidic orthodoxy in the region.

As Paul Hacker has shown on the basis of literary works, it is impossible to trace the succession of teachers of the Srnngēri mațha to a date before the mid decades of the fourteenth century. ${ }^{155}$ Epigraphic sources confirm this picture. "The inscriptional evidence”, observes Hermann Kulke, "leaves no doubt that Śrngēri became an important place only under Harihara I and Bukka I". ${ }^{156}$ Inasmuch as the earliest known pontiffs, Vidyā Tīrtha and Bhāratī Tīrtha, were recipients of Sangama munificence, we may venture a guess that it was under them that the matha was established, and that the Sangama brothers played a role in it that was by no means small. If this is true, the story of Śrngēri's help in founding the Vijayanagara state must be dropped in favour of the story of the latter causing the matha to be built!

Although popular as Vidyāraṇya, the pontiff was also known as Mādhavācārya. ${ }^{157}$ This seems to have been the name given him after initiation as a saint. 'Vidyāraṇya', forest of knowledge, was perhaps his title. It was an apt title indeed, as his two widely influential works, the Sarvadarśanasangraha and the Parāsaramādhavīya, amply demonstrate. Vidyāraṇya also wrote the Jivianmuktivivēka. ${ }^{158}$ In this outstanding work, he argued that knowledge of Brahman was not sufficient to cause liberation. Rather, the destruction of latent desires (vāsanākșaya), and of the mind itself (manōnāśa), through the regular practice of yōga, and leading the strictly disciplined life of a renouncer, "renouncing even the fact that he is a knower of Brahman", was essential for liberation. ${ }^{159}$

Vidyāranyya is also believed to be the author of the Sankaradigvijaya, which popularized the story of Śankara travelling across India and establishing maṭhas in the four corners of the subcontinent. Scholars, however, are divided about Vidyāraṇya's authorship of this work.

Vidyāraṇya's younger brother, Sāyaṇācārya, was a greater forest of learning. Bukka I (r. 1357-1377) and Harihara II (r. 1377-1404) commissioned him to carry out the ambitious project of writing commentaries on the Vēdas. The oeuvre that Sāyaṇa has left behind is at once prolific and profound. More than a hundred works are attributed to him. ${ }^{160}$ A resume of his works will place his significance in relief.

As he belonged to the Taittirìya school of the Kṛșna Yajurvēda, Sāyaṇa chose to commence his project by producing glosses on the Taittirìya Saṃhita, the Taittirìya

155 Cited in Kulke 1993: 235-236.

156 Ibid., 237.

157 Not to be confused with Madhvācārya (ca. 1197-98 - 1275-76), who propounded the dvaita system of vēdānta. We shall refer to Madhvācārya by his alternate name Ānanda Tīrtha throughout this work, in order to avoid confusion.

158 On this work, see Fort 1998: 97-113, and Goodding 2011.

159 Goodding 2011: 96.

160 On Sāyaṇa, see Galewicz 2009. 
Brāhmaṇa, and the Taittirīya Âranyaka. This accomplished, he took up the Rgvēda and its Brāhmaṇa and Āranyaka, viz., the Aitarēya Brāhmaña and the Aitarēya Āranyaka, for commentary, which was followed by the Sāmavēda and eight of its Brāhmanas, viz., the Tāndya, the Șadviṃśa, the Samavidhāna, the Ārșēya, the Dēvatādhyana, the Chāndōgya, the Samphitōpanișad, and the Vamśsa. The other commentaries he wrote included the ones on the Satapatha Brāhmana, the Śaunakiya recension of the Atharvavēda, and twenty adhyāyas of the Kaṇva Samhita. Sāyaña also produced anthologies like the Subhāṣita Sudhānidhi and the Purușārttha Sudhānidhi, and works on a number of topics, like Dharmaśāstras (the Prāyaścitta Sudhānidhi), etymology (the Mādhavīya Dhātuvrtti), medicine (the Āyurvēda Sudhānidhi), poetics (the Alamkāra Sudhānidhi), and vaidic rituals (the Yajñatantra Sudhānidhi). ${ }^{161}$ That this project was dear to the Sangama rulers is borne out by the fact that they made scholarly assistance available to Sāyaṇa. Harihara II granted an agrahāra to Nārāyaṇa Vājapēyayāji, Narahari Sōmayāji, Paṇụhāri Dīkṣita, Pañcāgni Mādhava, Nāgābharaṇa, and Nāgabhațta for their assistance in producing the commentaries. ${ }^{162}$ Sāyaṇa himself received a grant. In 1377, Harihara II donated an agrahāra to a number of brāhmanas. Sāyana was one of the recipients. ${ }^{163}$ We learn from an inscription of the time of Kṛṣnarāya (1513) that there was a village called Sāyanapura close to the capital, Vijayanagara. ${ }^{164}$ The village was perhaps founded, or renamed, in honour of Sāyana. So close was Sāyaṇa's relationship with the state that Cezary Galewicz recently chose to begin his monograph on the commentator by declaring that "[t]he legend of the man known to Indian history by the name of Sāyana will probably remain forever tied to another legend, that of the empire of Vijayanagara."165

The Śrngēri matha adhered to the advaita (non-dualist) school of Śankkara (ca. 788-820 CE). Or so it claimed, in spite of the tāntric influences it was subjected to. It is very likely, then, that the matha was not favourably disposed towards rival schools of thought and their establishments. One such establishment existed in the coastal town of Uḍupi down the ghäts, viz., the famous Kṛṣna temple with its eight affiliate mațhas. The Kṛ̣na temple was the wellspring of the dvaita (dualist) school,

161 Modak 1995: 17-18.

162 Galewicz 2009: 96-97.

163 Annual Report of the Mysore Archaeological Department 1915, p. 42. Modak 1995: $31-32$ speaks of another agrahara, Bukkarāyapura, granted in 1377 by Harihara II to sixty brāhmaṇas, including Sāyaṇa. He locates this grant in the Kṛ̣ṇarājapēțe tālūk (of Mạ̣ḍa district, although Modak refers to it as Hāsana district). I have not been able to trace this inscription. A similar inscription occurs in the Kṛ̣̣narājanagara tālūk (of the neighbouring Maisūru district), though, in which Harihara II granted Bukkarāyapura to several brāhmaṇas. However, Sāyaṇa’s name does not figure in the list of donees. If it is this grant that Modak is referring to, then it is likely that he has misread the word Hoysana (i.e. Hoysaḷa) occurring in it as Sāyaṇa. See Kn 77, Epigraphia Carnatica, Vol. 5 (revised edition).

164 No. 277, South Indian Inscriptions, Vol. 4.

165 Galewicz 2009: 31. 
which looked upon advaita as its biggest opponent. Understandably enough, Śrngēri shared a very difficult relationship with Udupi.

The dvaita doctrine was systematically formulated in the thirteenth century by the Vaiṣnava saint, Ânanda Tìrtha (ca. 1197-98-1275-76). ${ }^{166}$ He lived in Uḍupi for the better part of his life. He was a master of the vaidic works such as the Samhitas, the Brāhmaṇas, the Âranyakas, and the Upaniṣads. He is known to have studied advaita independently, as well as under a teacher of considerable renown, before registering his disagreements and setting out to build his own system. With his great erudition, argumentative prowess, and charisma, Ânanda Tìrtha went on to exercise great influence over the praxis of sainthood in southern India. We must examine his life at some length.

Although there is no unanimity concerning the dates of Ānanda Tìrtha, a manuscript of his Mahābhārata Tātparya Nirnaya used by Bhandarkar mentions Kali Era 4300 (CE 1199) as the date of his birth. ${ }^{167}$ While this date does not occur in the printed version of text, ${ }^{168}$ the succession list preserved in various monasteries mention 1197-98 as the year when Ānanda Tïrtha was born. That Ānanda Tìrtha lived for seventy-eight years enables us to place his death in the year 1275-76.

Ānanda Tìrtha is credited in hagiographic literature with the construction of the Kṛṣna temple at Uḍupi and its eight affiliate mațhas. ${ }^{169}$ There are no means to ascertain the veracity of this claim. The earliest legends concerning Ānanda Tìrtha are recorded in the Maṇimañjari, written by Nārāyaṇa Bhaț̣a, the son of one of his disciples Trivikrama. This fanciful work in eight chapters has, in fact, nothing much to tell us about Ānanda Tìrtha's life. Only in the eighth chapter is a terse and telescoped account given. There is no reference to the construction of the temple or the mathas in this account. An inscription from 1366 records a grant made by a certain Malliyadaṇnāyaka to the god of Uḍupi. ${ }^{170}$ The grant was made following the demise of a certain Sōvaladēvi, who had earlier made a grant. This suggests that the temple existed in the early half of the fourteenth century. However, the inscription is found in the Anantēśvara temple, not in the Kṛ̣na temple. The Kṛ̣na temple itself is known to have existed in the late fourteenth century. A grant was made to it in the time of Harihara II in $1395 .{ }^{171}$ Another grant came its way in $1396 .{ }^{172}$ We might on the basis of these evidences conclude that the temple existed in the later half of the fourteenth century. Given that Ānanda Tìrtha's death and the first known grant to the temple

166 On his dates, see Dasgupta 1991: 51-52.

167 Ibid., 51.

168 Ibid.

169 The eight mațhas are Phalimāru, Adamāru, Pējāvara, Puttige, Sōde, Kṛṣnapura, Śirūru, and Kaṇiyūru. The maṭhas were apparently named after villages originally held by them.

170 No. 306, South Indian Inscriptions, Vol. 7.

171 No. 299, Ibid.

172 No. 183, Ibid. 
are separated only by a little over a century, it is not unreasonable to accept that the temple was built during Ânanda Tīrtha's lifetime or within a few years or decades of his death.

Epigraphic reference to the mathas is not found before the seventeenth century. A record from 1615, when Vēdavēdya Tīrtha, the adoptee (karakamalasañjāta) of Vādirāja Tīrtha, held the pontificate, speaks of eight villages (aștagrāma) after which the mathas are named. ${ }^{173}$ However, the existence of the matha during Vādirāja's time is alluded to in legends concerning his life.

If the account given in the Maṇimañjarī is to be believed, Ānanda Tīrtha was born as the incarnation of Vāyu (the wind god) to destroy the doctrines of Sañkara, who taught Buddhism under the veil of vēdānta. The account itself is fanciful. It identifies Sankara as the son born out of wedlock to a widow. His real name is recorded as Maṇiman. He was an evil genius, who seduced a brāhmaṇa woman, converted people to his faith with the help of magic, and preached violence and immorality. His followers destroyed monasteries of their opponents, and indulged in sinful acts like killing cattle, women, and children. The teacher Satya Prajña was killed, and Prajñā Tìrtha converted to their faith by force. However, this line of teachers continued to practice their doctrine secretly. In this line was born Acyutaprēkșa. Ānanda Tīrtha was his disciple. ${ }^{174}$

The life of Ânanda Tìrtha is elaborately described on the lines of the prevailing hagiographic conventions in Nārāyaṇa Paṇdita’s Sumadhvavijaya. Like the Maṇimañjarī, this work regards Ānanda Tīrtha as an incarnation of Vāyu. Here is the story:

A brāhmaṇa called Madhyagēha Bhaț̣a lived at Pājaka in Paraśurāmakṣētra (the region between Gōkarṇa and Kanyākumāri) with his wife. He had a daughter, but there was no one to take his line forward as his two sons had died young. Madhyagēha Bhaț̣a and his wife prayed to Lord Anantēśvara for twelve years, and as a result, were blessed with a son. He was named Vāsudēva.

As a child, Vāsudēva was intelligent, inquisitive, and adventurous, and showed signs of wanderlust. The hagiographer attributes a number of miracles to the young boy, including the slaying of a demon, and curing his teacher's son of a chronic headache by blowing wind into his ear. After initial schooling in a gurukula, Vāsudēva decided to renounce worldly life and become a disciple of Acyutaprēkṣa, much against the wishes of his father. But before leaving, he prophesied that Madhyagēha Bhața would be blessed with another son. The prophecy came true. Acyutaprēkșa initiated Vāsudēva into sainthood, and conferred the name Pūrṇabōdha upon him. ${ }^{175}$ The boy was only ten years old at this time.

173 No. 302, Ibid.

174 Maṇimañjari, 6-8. For a summary of this account, see Dasgupta 1991: 52.

175 Elsewhere, and more popularly, he is known as Pūrṇaprajña. 
One day Pūrṇabōdha expressed his wish to travel to Kāśi, and take a holy dip in the Gañgā. Acyutaprēkșa was so deeply attached to his disciple that he was pained by the thought of his departure. Gangā appeased the guru and the śișya by appearing in the lake Anantasarōvara nearby. The days that followed were, however, marked by frictions between Acyutaprēkșa and Pūrṇabōdha. It began when Pūrṇabōdha defeated a vaiśēșika scholar called Vāsudēva in a debate, and impressed by it, Acyutaprēkșa decided to teach him a text of higher learning called Ișțasiddhi. This was an advaita text. Pūrṇabōdha pointed to several mistakes in it, which Acyutaprēkṣa had to concede. Pūrṇabōdha commenced a career in teaching, and began with māyāvāda (i.e., the advaita of Śankara). Acyutaprēkṣa now turned to a recitation of the Bhāgavatapurāna. The manuscript he had was different from the one that a disciple listening to it had in his possession. The disciple pointed to the differences in some verses, whereupon Pūrṇabōdha, who was also present there, declared which one of the two versions was textually authentic. When challenged by Acyutaprēkșa, he recited the subsequent section of the text to the surprise of those assembled there. Acyutaprēkșa asked him when he had memorized these difficult sections, as he had never seen him do so. Pūrnabōdha revealed that he had learnt them in his previous birth. Impressed by his scholarship, Acyutaprēkșa subsequently nominated him as his successor, and gave him the name Ānanda Tìrtha.

In the following days, Ānanda Tìrtha frustrated many scholars, including Jyēșțhayati, a friend of Acyutaprēkșa, and two Buddhist teachers, Buddhisāgara and Vãdisiṃha, in various debates. He then began his discourses on the vēdānta by commenting on the Brahmasūtras, and challenging the existing commentaries of the rival schools, especially advaita. Upon the request of many eminent teachers of the day, including Acyutaprēkșa's, he recited a new commentary on the Brahmasūtras.

Ānanda Tìrtha then set out on a tour of southern India in the company of Acyutaprēkṣa. It brought him to places like Viṣnumañgalaṃ near Kāsaragōọǔ, the Payasvini river valley, Tiruvanantapuraṃ, Kanyākumāri, Dhanuṣkōṭi, Rāmēśvaraṃ, Srīrangam, and other nearby places. At all these places, he had a sacred dip in the waters, and offered prayers. He also refuted rival teachers in debates at many places and won a number of admirers and followers. His next stopover was Śrimuṣna. Here, he caused a water-tank called Daṇuatīrtha to be excavated. From there he returned to the Payasvini valley, where at different places, he engaged in discourses and debates, defeating adversaries. He then wrote a commentary on the Bhagavadgita and presented it to Acyutaprēkṣa and Jyēșțhayati.

Ānanda Tīrtha now turned to the north and travelled to Badarikāśrama (Badrīnāth in Uttarakhand) with the intention of obtaining permission to write a commentary on the Brahmasūtras from its celebrated author, Vēda Vyāsa. In the course of the journey, he held discourses at various places, and routed advocates of rival schools in debate after debate. He also collected a number of books during the journey. Upon reaching Badarikāśrama, he presented the commentary on the Gìta to Lord Nārāyaṇa (Viṣṇu) at the Anantamațha, and obtained his approval. In the following days, he performed 
penances. Meanwhile, Vyāsa invited Ānanda Tīrtha to his âśrama in Uttara Badari. Ānanda Tīrtha travelled across the snowcapped mountains and reached Vyāsa's âśrama. The two giants met in a divine union. There, Lord Nārāyaṇa manifested in front of Ānanda Tīrtha in another form and asked him to write a commentary on the Brahmasūtras. Work on the commentary began at Badarikāśrama. Ānanda Tīrtha then travelled southwards and reached the river Gōdāvari, where a teacher called Sōbhanabhațta became his disciple. Ānanda Tīrtha returned to Uḍupi, where he presented his commentary on the Brahmasūtras to Acyutaprēkșa.

During his stay in Udupi, a storm caused a shipwreck in the sea. The ship was coming from Dvārakā. Ānanda Tīrtha saved the ship from destruction. The merchant who was sailing in the ship presented him with an image of Kṛ̣na in gratitude. Ânanda Tìrtha built a temple for Kṛ̣̣na at Uḍupi, and installed the image there. He then chastised a proud expert of yajñas, and had his teacher's son Vāsudēva perform a proper yajña. Then, he wrote the Tantrasāra, which laid out the rituals to be observed in the Kṛṣna temple.

After this, Ānanda Tīrtha set out on a second voyage to Badarikāśrama in the company of many disciples. He performed several miracles in the course of this journey, including making a king excavate a lake, walking on the river Gañga along with his disciples, humbling highwaymen, and rescuing his disciple Satya Tìrtha by killing the tiger that had attacked him. At Uttara Badari, Vyāsa presented him with eight stone sculptures made sacred by the presence of Lord Lakșmīnārāyaṇa. Vyāsa also instructed him to compose the Mahābhārata Tātparya Nirnaya. On his return journey, Ānanda Tïrtha walked over the river Gangā once again. During his four-month monsoon retreat (cāturmāsa) at Hastināpura, the Gañgā flowed down and bowed to him. At Kāśi, his disciples turned arrogant, and challenged him to a wrestling match. Ânanda Tïrtha defeated them effortlessly. Then he reduced the advaita teacher Indrapuri in a debate. Upon reaching Kurukṣetra, he dug the earth and revealed the mace used by him in his previous birth as Bhima, the second of the five Pāṇdava brothers. ${ }^{176}$ At Hṛ̣̣̂īēśa (Ṛṣīkēśa), Lord Rudra invited him to accept bhikṣa (alms) and made his devotee offer him bhikșā. Ânanda Tīrtha then came to Ișupāta where he prayed to Paraśurāma. At Gōvișaya (Goa), a king invited him and offered thousands of plantains and milk. Ānanda Tïrtha consumed them with ease. On another occasion at Gōvișaya, he consumed four thousand plantains and thirty pots of milk offered by a brāhmaṇa called Śankkara. ${ }^{177}$

From Gōvișaya, Ānanda Tìrtha returned to Uḍupi, and resumed his discourses on his dvaita system. Śōbhanabhaț̣a, whom we met earlier on the banks of the Gōdāvari, arrived at Uḍupi, and was initiated as Padmanābha Tīrtha. Another learned teacher

176 Bhīma is believed to be the son of Vāyu, and Ānanda Tïrtha, an incarnation of Vāyu.

177 Our hero seems to have been quite a foodie. The motif of consuming large quantities of food occurs again and again in the Sumadhvavijaya. It compares with the gluttony of Bhima in the Mahābharata. 
came from the Kalinga country, became his disciple, and returned home to attain fame as Narahari Tīrtha. Throughout this period, Ānanda Tïrtha's discourses continued in Uḍupi.

One evening, Lord Śēșa appeared in the sky with his entourage, which included the Sanaka brothers, ${ }^{178}$ to listen to the discourses. It created a great sparkle of light in the sky. Ānanda Tīrtha's audience was surprised by the light. The great teacher explained to them how the light was caused, and offered them a glimpse of Sessa and his entourage. Then Śẹșa revealed himself and gave a colourful description of Vaikunțha, the abode of Vișnu.

As the fame of Ānanda Tìrtha and his dvaita school began to spread far and wide, a number of adversaries arrived on the scene to challenge him. They approached Padma Tìrtha and Puṇ̣arīkapuri of the Cōla country for help. Puṇaraìkapuri challenged Ānanda Tïrtha to a contest, and predictably enough, he was defeated. Ānanda Tīrtha had entrusted the books in his possession to a certain Śankkarācārya. The māyāvādi opponents believed that our hero's knowledge was based on his books. So they employed a certain Padmanābha Tīrtha ${ }^{179}$ to steal the books. Learning of this, Ānanda Tīrtha came to Ēkavāța with Jyēṣțhayati, and humbled Padmanābha Tīrtha in a debate without the aid of books. The books were entrusted to the village headman with instructions to have them returned to Ānanda Tìrtha through the king.

The rest of the Sumadhvavijaya is rather dry (not that the events narrated above are otherwise). At Prāgyavāța, Ānanda Tīrtha spent one of his monsoon retreats. Here he spent his days in writing. It was here that the villagers brought the books stolen by Padmanābha Tïrtha to him. Ānanda Tïrtha refused to accept them, and advised them to have it returned through the king, Jayasiṃha. The king met him, and was moved by his spiritual charisma. He began to patronize the master, and became a trusted follower. Ānanda Tīrtha's adversaries were, nonetheless, unrelenting. They approached a certain Trivikrama Paṇdita and urged him to defeat Ānanda Tïrtha in a debate. But Trivikrama Pạ̣dita and his younger brother Śankara were already great fans of the dvaita school. A debate followed, which was more in the nature of a humble Trivikrama Paṇdita requesting Ânanda Tīrtha to clarify doubts on a number of points. It ended cordially. The rest of Ānanda Tīrtha's days were spent, predictably, in discourses and debates, routing rivals in both physical combats and intellectual exchanges, public works like building a check dam with a boulder to prevent flood in the river Bhadra, and filling the dried up lake of Daṇatīrtha in Saridantara by causing rain through a miracle. One of his last acts was to rescue his younger brother, who lived a woeful life after the death of his parents, from destitution. Ānanda Tìrtha initiated him as his disciple, who in course of time attained fame as Viṣnu Tīrtha.

178 According to the Purāṇas, Sanaka, Sanandana, Sanātana, and Sanatkumāra were four leading sages and the sons of Brahma.

179 Not to be confused with Śōbhanabhaț̣a, who was given this name after initiation. 
After living a long life of play (lìlā), Ânanda Tìrtha, who was by now popular as Madhvācārya, dissolved in the unmanifest, as they say in hagiographic parlance. He is believed to have suddenly vanished while discoursing on the Aitarey to his students at the Anantēśvara temple in Uḍupi.

The image of Ānanda Tìrtha that was constructed over the centuries, and recorded in the Sumadhvavijaya, has been crucial for the development of the dvaita system and its sainthood. There is in this image a combination of a number of attributes. Six of them are crucial for our purposes. One, Ānanda Tīrtha is endowed with divinity, emphasized by the fact that he is an incarnation of Vāyu, and meets with Vēda Vyāsa and Viṣnu. Two, he is known for his physical strength, represented by acts like slaying a tiger and defeating men in wrestling encounters. Three, he performs miracles like walking on a river. Note that unlike the miracles of future saints from other traditions (discussed in chapters 5 and 6), these acts are not meant for the benefit or welfare of others. Four, he travels far and wide, and wins over people to his school, mostly through debates. Five, he is a rebel who rejects, and fights against, orthodox learning. Six, he is the fountainhead of a new school of knowledge. Of these attributes, valour and the performance of miracles are certainly downplayed, and travel and divinity occupy an intermediate position as if they are inevitable components of sainthood. The greatest emphasis in the narrative is on the fact that the saint calls orthodox knowledge into question, and develops and nurtures his own school. This embedded hierarchy of attributes ${ }^{180}$ governed the image of sainthood in the dvaita school in the succeeding centuries. In the lives of the saints of Ānanda Tìrtha's tradition, valour and miracles was always peripheral in importance in articulating the personality of the saint, while travel and divinity were consistently recorded. The defining feature of the saint, however, was the challenge he posed to rival schools, and the force and conviction with which he argued his case. Although the dvaita school soon became one of the most deeply entrenched orthodoxies in the region, the noise it created by way of constant opposition to Śankkara's advaita enabled it to be represented as doctrinally radical. Here was the orthodox, masquerading as revolutionary.

The Madhva tradition has carefully preserved records of its genealogy beginning with Acyutaprēkșa. Each mațha had its own genealogy, too. Unlike the list of early teachers produced by the Śrngēri mațha, these were not fully invented genealogies, although many names are likely to have been smuggled into them at different times. Corroborative evidences in a number of cases establish the relative historical authenticity of the line of seers, although it is not to be taken as completely foolproof. Fantastic lists of succession were not, however, unknown, an instance of which is provided by Baladēva's commentary on the Brahmasūtras. ${ }^{181}$

180 We call it embedded because it is implicitly woven into the narrative rather than being stated explicitly.

181 Dasgupta 1991: 56. 
Thus, the Madhvas of Udupi were the first in the region to produce a list of succession with a relatively high degree of historical credibility that has been carefully preserved and continued well into our times. In this, they were in all likelihood inspired by the list of succession preserved by the viśiștādvaita schools of Tamilnadu. ${ }^{182}$ Here is one such list of $d v a i t a$ teachers of Udupi to the end of the nineteenth century: ${ }^{183}$

\author{
Ānanda Tīrtha (or Madhvācārya) \\ Padmanābha Tīrtha \\ $\downarrow$ \\ Narahari Tīrtha \\ $\downarrow$ \\ Mādhava Tīrtha \\ $\downarrow$ \\ Akṣōbhya Tīrtha \\ Jaya Tïrtha \\ Vidyādhirāja Tīrtha \\ $\downarrow$ \\ Kavīndra Tīrtha \\ Vāgîsa Tïrtha \\ $\downarrow$ \\ Rāmacandra Tīrtha \\ $\downarrow$ \\ Vidyānidhi Tīrtha \\ Raghunātha Tīrtha \\ $\downarrow$ \\ Raghuvarya Tīrtha \\ $\downarrow$
}

182 The viśiștāadvaita line of succession commenced with Nāthamuni, who compiled the works of the twelve Vaiṣnava saints, the Ālvārs, as the Nālāyira Divyaprabandhaṃ in the tenth century. He was succeeded by Pụ̣̣arīkākṣa, Rāmamiśra, Nāthamuni’s grandson Yāmunācārya, and Rāmānuja in that order. See Farquhar 1967: 240-242. See also Dutta 2014 for an account of early hagiographic representations of Rāmānuja.

183 Dasgupta 1991: 56. The historical significance of tracing such genealogies of succession will be discussed in chapter 4. 
Raghūttama Tīrtha

Vēdavyāsa Tīrtha

$\downarrow$

Vidyādhīśa Tīrtha

$\downarrow$

Vēdanidhi Tīrtha

$\downarrow$

Satyavrata Tīrtha

$\downarrow$

Satyanidhi Tīrtha

$\downarrow$

Satyanātha Tīrtha

$\downarrow$

Satyābhinava Tīrtha

$\downarrow$

Satyapūrṇa Tīrtha

$\downarrow$

Satyavijaya Tīrtha

$\downarrow$

Satyapriya Tīrtha

$\downarrow$

Satyabōdha Tīrtha

$\downarrow$

Satyasannidhāna Tīrtha

$\downarrow$

Satyavara Tīrtha

$\downarrow$

Satyadhāma Tīrtha

$\downarrow$

Satyasāra Tīrtha

$\downarrow$

Satyaparāyaṇa Tīrtha I

$\downarrow$

Satyakāma Tīrtha

$\downarrow$

Satyēșți Tīrtha

$\downarrow$

Satyaparāyaṇa Tīrtha II

$\downarrow$

Satyavit Tīrtha 
In his works, Ānanda Tïrtha is believed to have refuted the works of twenty-one commentators who came before him. The commentators are enumerated by Sēșa, who was a disciple of Chalāri Nṛsiṃhācārya, the author of a commentary on Nārāyaṇa Paṇdita's Sumadhvavijaya. The list includes the redoubtable Śańkara and Rāmānuja. ${ }^{184}$ Ānanda Tìrtha's works followed the widely established tradition of expounding the doctrine in the form of hermeneutically oriented commentaries on the prasthānatraya, ${ }^{185}$ and other vaidic and brāhmanical works. Thirty-seven works are attributed to him. These included a commentary on the Bhāgavatapurāna, the Bhagavadgīta, the Brahmasūtras, Upaniṣads like the Aitarēya Upanișad, the Taittirìya Upanișad, the Chāndōgya Upanișad, the Bṛhadāranyaka Upaniṣad, the İ́̄ōvāsya Upaniṣad, the Kațhōpaniṣad, the

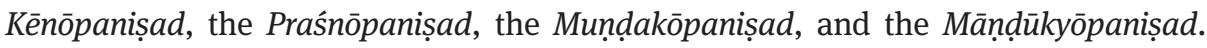
Besides, he wrote commentaries on parts of the Rgvēda, the Aitarēya Brāhmaña, and the Aitarēya Āranyaka. His masterpiece was the Mahābhārata Tātparya Nirnaya, allegedly an exposition of the real meaning and spirit of the Mahābhārata. In this work, he described the world as real and characterized by five distinctions (pañcabhēdā), viz., the distinction between the self (jīva) and god (iśvara), the distinction between one self and the other, the distinction between matter (jaḍa) and god, the distinction between matter and matter, and the distinction between matter and the self. ${ }^{186}$ This theory was the cornerstone of his dvaita school.

Ānanda Tìrtha was the pioneer of the new vaidic orthodoxy in the region. The dvaita doctrine he promulgated was certainly a serious challenge to the advaitic orthodoxy, as it affirmed the reality of the world. The world, according to this doctrine, was not $m \bar{a} y \bar{a}$, but a substantial reality. But the first step towards upholding the reality of the world was already taken a century before Ānanda Tïrtha, when Rāmānuja systematized the tenets of the viśiștâdvaita school. We must, therefore, dwell at some length on Rāmānuja's intellectual contributions in order to understand how he recast the debate on the ontological status of the world.

Rāmānuja (ca. 1017-1137) was a profoundly influential teacher. He was a disciple of Yāmunācārya (ca. 966-1038), who in turn was the grandson of Nāthamuni (ca. 900950), who had compiled the works of the twelve Vaiṣnava saints of Tamilnadu, called Ālvārs, in the Nālāyira Divyaprabandhaṃ. Rāmānuja thus had a rich intellectual legacy to inherit. It was a combination of four elements: i) classical vēdānta articulated in the form of commentaries on the prasthānatraya texts, ii) the ideal of devotion or bhakti with its emphasis on intense personal relationship between the devotee and the deity,

184 Ibid., 53.

185 The prasthānatraya or 'the three movements' are the Brahmasūtra of Bādarāyaṇa (i.e. Vēda Vyāsa), the Bhagavadgita, and the Upanișads. The vaidāntic traditions of India, which include the advaita, the dvaita, the visisistādvaita, the dvaitādvaita, the śuddhādvaita, and many other schools, regard the prasthānatraya as the source of their authority. Most vaidāntic doctrines are in the form of commentaries on the prasthānatraya.

186 Mahābhārata Tãtparya Nirṇaya, 1.69-71. 
iii) the temple-centred āgamic rituals of the tāntric Pañcarātra tradition, and iv) the paurānic ontology narrativized in the Bhägavatapurāna, and more importantly, in the Viṣnupurāna..$^{187}$

Rāmānuja made a significant departure from Śańkara's scheme of things when he identified the world as real and substantial. ${ }^{188}$ Matter was, therefore, a major ontological factor in the articulation of his doctrine. The Buddhists had reflected upon the nature of matter for a long time. But unlike the Buddhist systems in which a specific god was absent, the doctrine of Rāmānuja had the quality of a theology. God (in his form as Viṣnu) was central to this system. Recognizing the world as real and substantial, then, generated the need for describing the difference between god and the world, and how they were connected to each other. In his Śrībhāṣya, a commentary on the Brahmasūtras, Rāmānuja elaborated upon this idea of difference in a matter of fact way by emphasizing that the perception of difference and their recapitulation during memory were possible only because each object had an essential attribute of its own, which made it different from the other. In the absence of such essential attributes, it would be impossible to distinguish between, say, a horse, and an elephant. ${ }^{189}$ Rāmānuja argued that experience, in its forms as knowledge, comprehension, and consciousness, is simply an attribute of the experiencing self. ${ }^{190}$ The individual self, therefore, possesses an attribute, viz., the faculty of knowing. It is not merely a reflection of the supreme self devoid of attributes, as Śankkara had claimed.

This foregrounding of difference had its logical corollary in the fact that the difference between the self and the body had also to be clearly understood. Thus, reflections on the body came to occupy an important position in this system of theology. Rāmānuja addressed this question by regarding Brahman as śarīi, i.e., embodied, or the one endowed with a body. Interpreting verses from the Viṣnupurāna, he argued that Brahman possessed a body, variously called śarìra, rūpa, tanu, aṃśa, śakti, and vibhūti by the Purāna. In this theory of embodied Brahman, the śarìri was the substance, the sarira or body, its attribute. This was a radical move away from the manner in which the Bhagavadgitā, an important prasthānatraya text, framed the relationship between the body (dèha or śarīra) and the embodied one (dēhi or śarīi). Although the Gitā dwelt at length on the (phenomenological) presence of the body, its avowed position was that the body was, in the ultimate analysis, corporal, and subject to decay, unlike the ätman, which was extra-corporal, and eternal, indestructible, and immeasurable. ${ }^{191}$ The body, was, therefore undesirable. Making

187 The influence of the Bhägavatapurạna's order of things is only implicit and embedded in Rāmānuja's works, his explicit and long-standing engagement being with the Viṣṇupurāna.

188 See Bartley 2002: 27-68 (i.e. chapter 2) for a discussion.

189 Śrībhāṣya, 1.1.1.

190 Ibid. However, Rāmānuja hastens to clarify that experience itself has no attributes, as it is not an object to be known.

191 Bhagavadgītā, 2.18. 
this "undesirable" object substantial, and more crucially, an attribute of Brahman, changed the way in which South Asian traditions of renunciation in particular and intellectual traditions in general looked at the world.

Isn't there a distinction between the śarīi and the śarira in Rāmānuja's scheme of things? Yes, there is, and this is one of its points of emphasis as well. But the crucial point is that the sarira is substantial (dravya) inasmuch as the world is substantial, and at the same time, an attribute (guna) of the sariri. Everything that exists is identical with Brahman only by virtue of the relationship of body and soul between them. Whatever is different from Brahman exists as an entity only by being his body. ${ }^{192}$ It is thus that difference (bhēda) and likeness (abhēda) are both affirmed simultaneously. How can a substance be a substance, and at the same time the attribute of another substance? The answer is provided through the simile of a lamp and the light emanating from it. The light is real, and substantial in its own right. At the same time, it is an attribute of the lamp that is also real and substantial. ${ }^{193}$ This relational ontology, called dharmabhütajñāna, ${ }^{194}$ endowed an attribute with substance. Knowledge, i.e., brahmajñāna, involved a proper understanding of this relational ontology and its causes. The intention to know could arise without the intervention of god. As Elisha Freschi observes, "Intentions need the support of God to be turned into actions but one can conceive independently the desire to take refuge in God and this is the root of one's future attitudes and deeds."195

How was brahmajñāna to be known? Rāmānuja's answer to this question was simple and disappointingly prescriptive: brahmajñāna was to be learnt from a guru. It is the guru who teaches the aspirant to say: "In me all is born, by me all things are sustained and in me all things are dissolved. I am the secondless Brahman” and that "I am that Brahman that illuminates all things, which is truth, knowledge and bliss absolute”. The knowledge thus acquired is a knowledge from the mediate (parōkșa), which over time becomes immediate (aparōkșa). ${ }^{196}$ An intensely personal bond between the guru and the disciple is called for, as P.N. Srinivasachari writes in his monograph on the visisistādvaita:

the àtman, who belongs to Brahman, somehow superimposes on himself the idea that he belongs to prakrti, sleeps in and as matter in the pralaya state, identifies himself with the body of a god or an animal or a man in creation and subjects himself to the wheel of samsāra with all its hazards and hardships till he is made to realise his folly by a loving guru. ${ }^{197}$

192 Śrībhāṣya, 1.1.1.

193 Srinivasacari 1943: 300.

194 Ibid., 33.

195 Freschi 2015: 292.

196 Srinivasachari 1943: 89.

197 Ibid., 136-137. 
The loving guru is therefore central to the acquisition of knowledge and the practice of sainthood. Thus, an aspirant "cannot rely on the inner light of reason without the grace of God and the guru". ${ }^{198}$

This emphasis on a personal and emotional bond with the guru cannot be seen as an inherent trait of renunciation in South Asia. Some of the oldest works on renunciation from the subcontinent present no signs of such intimacy. In the Praśnōpanișad, for instance, the relationship the teacher Pippalāda shares with his six students is remarkably formal. One may even call it mercenary. Having learnt the knowledge of Brahman, the students pay tributes to Pippalāda-in words and in kind-and leave him without cherishing any emotional bonds. No residues of intimacy are left behind. We never come across any attempt to establish an enduring bond between the guru and the sisya ${ }^{199}$ This seems to have been the case at least till the early second millennium CE. In the absence of any attempt to address this question historically, it is difficult to say when, why, and how the practice of configuring the guru-śișya relationships in intimate terms gained currency. All that can be said is that it was well known by the end of the twelfth century when the forebears of the later day Viraśaivas began to represent themselves as being protected by the eight-fold armours (așțāvaraṇa), beginning with the guru. ${ }^{200}$ As far as I can trace, the earliest expression of the new chemistry between the teacher and the student goes back to the Mantrayāna school of Buddhism in Tibet. The story of Nārōpa's (ca. 1016-1100) impassioned engagement with his guru Tilōpa (ca. 988-1069) seems to embody the first known instance of its kind. Nārōpa's patience and conviction about the infallibility of Tilōpa makes him endure a number of recurring ordeals that the latter expects him to overcome. Nārōpa, nevertheless, remains unshakable in his resolve and reverence for his guru. ${ }^{201}$ As intense as this is the relationship the celebrated Milarēpa shared with his teacher Marpa, who was the greatest of Nārōpa's students. ${ }^{202}$ This new ideal seems to have soon found its way into Nepal from where it was carried to the north Indian plains, perhaps by the Nātha (Kānphațā or Bārāpanthī) yōgis. Gōrakṣa (Gōrakhanātha), to whom the founding of the Nātha tradition of renunciation is attributed, is said to have shared a close relationship with his guru, Matsyēndra. ${ }^{203}$

The position the guru enjoyed in South Asian systems of renunciation after the twelfth century was ethically far-reaching, if not decisive. What it involved was a displacement of agency (kartrtva) and action (kriya). The self freed itself from

198 Ibid., 174.

199 We are discussing the relationship involved between the teacher and the aspirant disciple in the practices of renunciation, not the formal gurukula education during brahmacarya.

200 The eight armours are guru, linga, janigama, pādōdaka, prasāda, vibhūti, rudrākșa, and mantra. For a discussion, see Nandimath 2001: 326-32.

201 On Nārōpa, see Guenther 1995.

202 On Milarēpa, see Evans-Wentz 1950.

203 Briggs 2007: 229-34. 
the burden of agency and action by investing them in the guru, who, though real, functioned as an abstract figurehead as far as the dynamics of this displacement was concerned. Thus, guru could be invoked as a concept-as the Viraśaivas did by including him in the aștāvarana-without there being an explicit need to invoke a specific individual as guru to whom obeisance is paid. This abstraction enabled the sixteenth-century poet Mēlpattūr Nārāyaṇa Bhaț̣adiri from the neighbouring Kerala to transform everything in the world into a guru from which he has something to learn. If the god-compassionate makes up his mind, anything can turn into a source of learning. ${ }^{204}$ The earth teaches patience, the wind detachment, and the sky-teacher (gaganaguru) immanence. ${ }^{205}$ Water teaches purity, fire omnipresence, and the sun and the moon, changelessness behind the shifting hues and shades. ${ }^{206}$ The hunter, the python, the ocean, the fly, the beetle, ${ }^{207}$ the elephant, the bee, the deer, the fish, Pingalā the courtesan, the pelican, ${ }^{208}$ the child, the virgin, the artisan, the snake, ${ }^{209}$ the spider, the hornet, and the body which teaches renouncement by reminding us of its ultimate fate of ending up as filth or ash, ${ }^{210}$ are all transformed into teachers. With agency and action displaced from the self, what remained was the act-without the intentional component-and its result. Both were designated as karma. The question of agency was of course not completely dismissed, as the self was always said to be susceptible to the burdens of accumulated karma. But the karma question became less and less troubling over the centuries, particularly after the fifteenth century, when many new techniques-like listening to the Rāmāyaṇa, the Mahābhärata, the Bhāgavatapurāna, or stories from the paurāṇic tradition, or chanting the god's name, or visiting centres of pilgrimage-were invented to secure liberation and freedom from the backlashes of karma. Even heinous crimes such as brahmahatya (killing a brāhmaṇa) could be absolved with ease. The figure of the guru and its avowed relationship with the self enabled the transformation of agency and actionwhich were functionally real though conceptualized as displaced-into a ritualistic, recursive, and therefore non-existent form, making the self's powers of volition ethically redundant. The displacement of agency and action-which was more of a deferral than displacement-had a historically significant outcome. It released the self from the question of responsibility. The new self engaged in duty (also called karma), but without being responsible or answerable to anyone. It produced knowledge and beauty, wielded authority, created wealth, and longed for the realization of Brahman, all for their own sake and not because the self nurtured a sense of responsibility.

204 “tvat kāruṇyē pravṛttē ka iva nahi gurur lōkavṛttē pi bhūnan”, Nārāyaṇīyaṃ, 93.3.

205 Ibid.

206 Ibid., 93.4.

207 Ibid., 93.5.

208 Ibid., 93.6.

209 Ibid., 93.7.

210 Ibid., 93.8. 
It should therefore not be surprising that no Indian language had an equivalent for the word 'responsibility' in its vocabulary, until words like honegārike, javābdāri, uttaravādittvam, cumatala, zimmēe $\bar{a} r \overline{\text {, }}$, and so on were coined or appropriated in the nineteenth and the twentieth centuries to signify it. ${ }^{211}$

Invoking the guru was one way of transcending responsibility. ${ }^{212}$ There were perhaps many other ways of doing it. One of them is of particular interest to us. This was lìlā, or the concept of a cosmic play as constituting the universe.

Lìlā was a worldview, or more appropriately, an ontology of the world. It described the world as a play of the supreme self or Brahman, variously identified as Rāma, Kṛ̣ṇa, Śiva, Viṣnu u, etc. Whether this supreme self was endowed with essential attributes (guna) was of course a theological question often debated..$^{213}$ But its ability to orchestrate the cosmic play, either consciously or through the mediation of sakti or $m \bar{a} y \bar{a}$, was widely accepted after the twelfth century, and more pronouncedly after the fifteenth century. The visible and the invisible worlds, which constitute the universe, were the unfurling of this play. The world did not exist as anything other than the play. Thus, the supreme self was the cause of the world. According to some traditions, Brahman created the world. According to others, the world was always present without being subjected to creation or destruction, and merely reflected in the form of the manifest world, like the city reflecting in the mirror, due to $m \bar{a} y \bar{a} .{ }^{214}$

Rāmānuja is among the earliest teachers to argue that the manifest world is a lìlā of god. The Śribhāṣya begins by invoking god as the one who creates, maintains, and destroys the whole world with his sport. ${ }^{215}$ Rāmānuja accepts the position of the Brahmasūtras that the world is but a mere play (of Brahman) ${ }^{216}$ and that there was no motive behind creation. ${ }^{217}$ He further refutes charges of partisanship and cruelty on Brahman for having created an unequal world by endorsing the Brahmasutras' idea of dependence (sāpēkșa) in creation. Brahman, says Rāmānuja, depends upon the

211 Here, we make a conceptual distinction between duty and responsibility. Duty is enforced by an external agency like state, community, family, convention, law etc., whereas responsibility emerges from within, and is governed by one's conscience.

212 Literature concerning the image of the guru in south Asia after the twelfth century is neither extensive nor compelling. See Devadevan 2010c: 263-308 for a preliminary discussion. The importance of guru in the emerging religious systems of this period has not gone unnoticed, though. "It is peculiar", writes Galewicz, "for many religious traditions of medieval India, and most characteristic of the group of works we are dealing with here, that the persons of gurus and the institution of the guru as such are paid the highest possible respect." Galewicz 2009: 54.

213 This refers to the saguna-nirguna debate.

214 The simile is from the popular Dakṣināmūrti Stōtraṃ 1 ("viśvaṃ darpaṇa dṛ́syamāna nagarī tulyạ̣").

215 "akhila bhuvana janma sthēma bhañgādi līlē", Śrībhāṣya, invocation.

216 "lōkavat tu lìlā kaivalyaṃ”, Brahmasutras, 2.1.33.

217 "na prayōjanavattvāt”, Brahmasutras, 2.1.32. 
karma of the souls for creation. Hence a world full of suffering and inequality. ${ }^{218}$ This unconvincing argument is based on the authority of the Bṛadāranyaka Upanișad, that virtue and vice lead to virtue and vice, respectively. ${ }^{219}$ How, then, did Brahman create the first soul and the first karma? Rāmānuja states, on the authority of the Kațhōpaniṣad, the Bṛhadāranyaka Upanișad, and the Bhagavadgitāa, that the soul, karma, and matter have no beginning. ${ }^{220}$ At the same time, lìlā is independent of the karma or past actions of Brahman, and also not directed towards a goal in the future. “The Lord's action”, as John Braisted Carman summarizes it, "is not determined by karma, nor does he have to achieve some unrealized goal, for all the Lord's desires are already fulfilled. When the Lord periodically creates, maintains, and destroys the universe, he acts in sovereign freedom for the sheer joy of self-expression". ${ }^{221}$ So, it is the sheer joy of self-expression that makes god engage in the great cosmic sport of creating matter (jada) and the body (śarira) (that are anyway already in existence, as they have no beginning!), imbuing them with reality and substance, and making them attributes of his own substance.

Rāmānuja was certainly borrowing the idea of līlā from the Bhāgavatapurāṇa and Nammālvār's Tiruvāymoli. ${ }^{222}$ In the Tiruvāymoli, god is said to be playing in the poet's heart without showing him the body. ${ }^{223} \mathrm{He}$ is a miracle-worker ${ }^{224}$ and a marvel of contradictions, ${ }^{225}$ who created the great drama of the Mahābhārata war. ${ }^{226}$ These images might have gained wide popularity after Nāthamuni incorporated them into the Nālāyira Divyaprabandhaṃ, conferring them with canonical status. Rāmānuja had access to these images; for wasn't he the disciple of Nāthamuni's grandson Yāmunācārya? ${ }^{227}$

The visisțādvaita was a revolutionary doctrine. It brought the world in general and the body in particular to the centre-stage of reflection. Earlier systems mostly deployed the body and the world for purposes of similes or to establish their unreal and/or destructible status in relation to Brahman. Medical treatises, like the Suśruta

218 Śrībhāṣya, 2.1.34.

219 Bṛhadāraṇyaka Upaniṣad, 3.2.13.

220 Śrībhāṣya, 2.1.35. This is a major inconsistency in Rāmānuja’s system, but Rāmānuja seems to be in no mood to resolve it.

221 Carman 1994: 83-84.

222 Note, however, that the Bhāgavatapurāna was not of much importance for Rāmānuja, and even Vēdānta Dīkșita. Rāmānuja, instead, held the Viṣṇupurāṇa in high regard.

223 Tiruvāymoli, 6.9.5, as translated in Ramanujan 1993: 21. The Tiruvāymoli is a Tamil text, and the poet does not use the expression līlā in it, although the idea is embedded in his imagery.

224 Ibid., 7.8.1.

225 Ibid., 7.8.3.

226 Ibid., 7.4.5.

227 The question of līlā awaits systematic historical research. Devadevan 2010c: 263-308 makes a set of preliminary assessments. The essays compiled in Sax 1995 offer a good starting point for further research. Also see Hawley 1981. 
Samhitā, were of course professionally obliged to discuss the body. But it was rare to find discourses on the body in texts expounding religious systems. The Jaina theorists were among the earliest to acknowledge the body as real. The Yōga school and the Bhagavadgit $\bar{a}$ also laid emphasis on the body as real, and prescribed methods for its nurture and/or control. However, not until the twelfth century did the body figure as an essential object of reflection in South Asian systems of thought. The viśiștādvaita endowed the body and the world with an ontological status that was at once real and substantial.

An understanding of the self or the supreme would henceforth be incomplete without an understanding of the body. This was the first step in the evolution of the consciousness that the body and the world were available for reflections, and their ontologies open to causal explanations. Neither the Bhagavadgitā nor systems like Yōga ever attempted to offer causal explanations for the existence or creation of the body. That this worldly shift in theology occurred at a time when the rank and file of landholders expanded exponentially and brought forth a deeply entrenched class of peasant proprietors who asserted their selfhood and worldly wealth in ways hitherto unknown explains why the visisțtādvaita became the most influential system of theology in south India after the twelfth century, influencing even systems that were antagonistic to it, as we shall see. Thus, when Ānanda Tïrtha produced his doctrine of five distinctions, the idea that the world was real was already known to south Indian theological systems for over a century. It was in this context that Vidyāranya, the arch Advaiti of the fourteenth century, advocated not only the destruction of latent desires (vāsanākșaya), but also the destruction of mind itself (manōnāśa). He certainly knew that the body was real, although his denial of its reality was remarkable for its refined reasoning.

Vidyāraṇya died in 1386. Sāyaṇa outlived him by only a few months. He passed away in 1387. Twelve years later, the famous Chisti saint of Dilli, Sayyīd Muhammad al-Hussaynī, better known as Hazrat Khvājā Bandānavāz Gēsūdarāz, reached Daulatābād. The Bahmani ruler Firūz Śāh accorded him a warm welcome, invited him to Kalaburagi, and offered him space to build his khānkāh (hospice). Bandēnavāz, as the saint came to be known in the region, was already seventy-nine years old at that time. He lived in Kalaburagi until his death at the age on 101 on 1 November $1422 .{ }^{228}$

Bandēnavāz was the son of Sayyīd Yūsuf al-Hussaynī of Khūrāsan, who had become a disciple of Hazrat Nizāmẹ-ud-dīn Auliyā in Dilli. His family claimed descent from Muhammad, the Prophet. Yūsuf was popularly known as Rājū Kattāl. Bandēnavāz was born in Dilli. At the age of seven, in 1328, the family moved to Daulatābād when Muhammad bin Tughlak ordered migration of the residents of Dilli to his new capital. Rājū Kattāl died in 1330 and was interred in Daulatābād. Three years later, in 1333,

228 The following account of Bandēnavāz's life is based on Eaton 2005: 33-58 (i.e., chapter 2). Also see Papan-Matin 2010: 175-178 and Jestice 2004: 311 for a brief biography. 
the family returned to Dilli. In 1336, Bandēnavāz and his brother Sayyīd Candān al-Hussaynī became disciples of the Chisti saint, Nāsir-ud-dīn Mahmūd, popularly known as Cirāg-e-Dilli (the light of Dilli). Nāsir was the preeminent disciple of Nizāṃud-dīn Auliyā, who had died in 1325. Under his tutelage, Bandēnavāz turned into a recluse and spent long periods in isolation, lost in books and meditation. Candān al-Hussaynī continued with his worldly pursuits. Bandēnavāz was seriously affected by the cholera (or a spillover of the great plague that caused the Black Death in Europe, Central Asia, and China?) that struck Dilli in 1356. Nāsir-ud-dīn nursed him back to life, and recognized him as his spiritual successor through the symbolic act of giving him his prayer carpet, before dying in September that year. For the next fortytwo years, Bandēnavāz lived in Dilli and attracted a wide following. He left Dilli on 17 December 1398 after learning of Tīmūr's destructive march towards Dilli. He travelled through Bahādurpūr, Gvāliyar, Jhānsi, Candēri, Vaḍōdarā and Khaṃbaṭ, and reached Daulatābād late in 1399, from where he reached Kalaburagi at the instance of Firūz.

The relationship between Firūz and Bandēnavāz remained cordial until 1403. In that year charges of heresy came to be made against Bandēnavāz on the grounds that the works he taught in his hospice included the heretical Fusus al-Hikham of Ibn al-'Arabi (1165-1240). Firūz's brother Ahmad S̄āh Bahmani, who was a claimant to the throne, threw in his lot with Bandēnavāz. The Shaikh seems to have supported Ahmad's claim to the throne. His relationship with Firūz soared. In 1409, Bandēnavāz moved to a new location away from the fort. The Sultān also grew contemptuous of the Shaikh as the latter, who excelled in ecclesiastical learning, was poor in secular sciences like rhetoric and geometry, which the Sultān had mastered..$^{229}$ In 1422, when Firūz was on his sickbed trying to promote his son as the next Sultān, Ahmad paid a visit to Bandēnavāz, and on 21 September, usurped the throne after a brief confrontation with Firūz's forces. Firūz died on 2 October. A month later, on 1 November, Bandēnavāz also breathed his last. Before his death, Bandēnavāz nominated his son Sayyīd Asghar al-Hussaynī as his successor to the khānkāh. Thus was introduced the principle of hereditary succession among the Süfis in the Deccan. ${ }^{230}$ Ahmad also granted land to the khānkāh, although he soon stopped patronizing the Chisti order and turned to the Kādiris of Iran as part of a change in royal policy. The control over land, hereditary succession, the brief support extended by the Bahmani state, and the image of a ripeold man rebelling against the Sūltan, these factors led to the popularity of Bandēnavāz in the region. Shortly after his death, his mausoleum in Kalaburagi became a leading centre of pilgrimage. It has continued to be so well into our times.

Bandēnavāz was a proponent of sama', the practice of listening to the singing of mystical poetry to the accompaniment of percussion instruments. The band sama' (closed band), involving a limited audience and the use of a tambourine, was his

229 Eaton 2005: 52.

230 Ibid., 55. 
innovation. Singing turned out to be a powerful means of propagating Süfism in the Deccan.

Bandēnavāz was the Sāyaṇa of the Islamic world. He wrote prolifically in Arabic, Persian, Urdu, and Dakhni, producing nearly two hundred books on a variety of ecclesiastical themes. These included commentaries on the Korān and the Hadiths.

The projects of Rāmānuja, Ānanda Tīrtha, Vidyāraṇya, Sāyaṇa, and Bandēnavāz were harbingers of a greater project undertaken in the fifteenth century at Hampi, whose impact was pervasive and whose consequences, far-reaching. The impetus for this project seems to have come from Mahalingadēva, a resident of Puligere (where Addayya destroyed a Jaina basadi three centuries earlier). It was carried out under the able supervision of Jakkaṇārya and Lakkaṇṇa Daṇḍēśa, two military commanders under the Vijayanagara king Dēvarāya II (r. 1424-1446), who were also entrusted with civil assignments as functionaries of the state. This project was instrumental in the consolidation of beliefs, practices, and narratives that would eventually come to congeal as Virraśaivism.

Mahalingadēva bore titles such as Puligerepuravarādhīśvara and Vārānasiñndra. He wrote the Ékōttaraśatasthala and a commentary on Allama Prabhu's vacanas under the name, Prabhudēvara Șațthalajñānacāritravacanada Tìke. With this commenced the historical enterprise of compiling the vacanas of the twelfthcenturies śaranas, producing glosses on them, and composing hagiographies of the śaranas and narratives of encounters between them. An early attempt in this direction was made in 1369, when the poet Bhīma wrote the influential Basavapurāna, ${ }^{231}$ a hagiographic account of the life of Basava, inspired by Pālkurike Sōmanātha's Basavapurānamu in the Telugu (ca. 1200). But the new enterprise was more orthodox than Bhìma's, and doctrinally rigorous and elaborate. Mahalingadēva's disciple was Kumāra Bañkanātha, who wrote the Șațsthalōpadēśa and the Prabhudēvara Ṭīkina Vacana. Jakkaṇārya was Ban̉kanātha's adopted son (karajāta), and his entry into Vijayanagara service gave a great fillip to the project. Jakkana was himself the author of the Ékōttaraśatasthala, inspired by Mahalingadēva's work of the same name. Mahalingadēva had another disciple, known by the title Girīndra. He wrote a commentary on Jakkaṇa's Ēkōttaraśatasthala.

Among the other illustrious participants in the project, Lakkaṇna Daṇ̣̂esa has already been named. He wrote the encyclopedic Śivatatvacintāmaṇi. Maggeya Māyidēva was another contributor, who lived in Dēvarāya II's time. He came from Aipura (also called Magge?) on the river Malaprabha. ${ }^{232}$ He was the author of the

231 This epoch-making work has yielded the largest number of manuscripts for a Kannada literary text, after Kumāravyāsa's version of the Mahābhārata in the language, the Karṇāta Bhārata Kathāmañjari.

232 It is not unlikely that he was a weaver with the name, Maggada Māyidēva, i.e., Māyidēva of the Magga ('the loom'). 
Śatakatraya, the Anubhavasūtra, the Ėkōttaraśatasthalașațpadi, the Șațsthalagadya, the Prabhugita, and a few vacanas. The works of Gurubasava, a lesser-known writer, were innovative in form, framed as they were as dialogues between a guru and his disciple. He wrote seven works, the Sivayōgāngabhūṣaṇa, the Sadgururahasya, the Kalyānēesvara, the Svarūpāmṛta, the Vrṣabhagita, the Avadhūtagita, and the Manōvijaya. These are collectively known as Saptakāvya. At the instance of Gururāya, a mahāpradhāna under Dēvarāya II, Candra alias Candraśēkhara wrote the Virūpākșāsthāna and the Gurumūrti Śankkaraśataka. Candra was a polyglot, and claimed proficiency in eight languages.

The Vijayanagara court hosted a number of renouncers, who lived in different parts of Karnataka at the time. Tradition identifies 101 of them, and calls them the nürondu viraktaru or the 101 Viraktas. Some of them were also poets. Among them was Cāmarasa, the author of the outstanding hagiographic account of the life of Allama Prabhu, the Prabhulingalile. This work was recited to great appreciation in Dēvarāya II's court. Kallumațada Prabhudēva was another Virakta known for his literary works. He composed the Lingalīlāvilāsacāritra, and a commentary on the Mantragōpya attributed to Allama. The recalcitrant Karasthala Nāgalinga, a goldsmith from southern Karnataka, was a third Virakta credited with literary compositions. He wrote a number of vacanas and a short work called the Karasthala Nāgidêva Trividhi.

Closely related to the Vijayanagara project was the work of Śivaganaprasādi Mahādēvayya, who wrote the Śūnyasampādane, a narrativized anthology of twelfthcentury vacanas centering on the life of Allama. It turned out to be a successful work, inspiring three more Sünyasampādanes in the fifteenth and the sixteenth centuries, one each by Halageyārya, Gummaḷāpurada Siddhalinga Yati, and Gūlūru Siddhavīraṇnọ̣eya.

It is not easy to characterize the nature of this great project, because although they were addressed to a limited audience, they engaged with multiple concerns and served multiple purposes. It tried to consolidate and integrate the several Śaiva traditions that had sprung into life after the organized groups of the earlier period, such as the Kālāmukhas and the Kāpālikas, had begun to show signs of disintegration. Many disorganized groups, like the Viraktas, the Ārādhyas, the Jangamas, the Ārūḍhas, etc., were brought together as part of this integration. Their orders of succession, practices of renunciation, and systems of knowledge were elaborated, widely commented upon, and defined as constituting Viraśaivism. Saints from various other traditions were also appropriated. For instance, Cāmarasa's Prabhulingalīe speaks of Allama Prabhu confronting Gōrakșa (Gōrakhanātha, the founder of the Nātha or the Kānphațā tradition), at the end of which the latter becomes his disciple. ${ }^{233}$ This legend is repeated in the Sūnyasampādane. Muktāyakka is another saint who figures

233 Prabhulingalīe, 19. 
prominently in the works of this project. She might be none other than Muktābāi, the sister of Jñānēśvara and a major figure in the Vārkharī tradition of Maharashtra.

These works were informed by a new image of selfhood that had been evolving since the twelfth century. This self was the reified expression of men and women who had in the course of the preceding centuries gained greater access to wealth in the form of land and money, and begun to assert their political authority at the locality and the regional levels. In other words, this self was the creation of a class that was affluent, or at least confident about its potentials of upward mobility. Like the individual merchant who began to dissociate himself from the merchant syndicates, and like the peasant proprietors who had begun to transact business independently of the $n \bar{a} d u$ assembly, this new self was beginning to assert its autonomy in different ways. It was most ingeniously done with the help of discourses, reflections, and commentaries on the human body.

In most traditions, the body was represented as foul, polluted, and undesirable. A clear distinction was made between the body (dēha or tanu) and the self (tānu) or the soul (âtman) that resides in it. The idea was to argue that the self continued to be immaculate and incorruptible in spite of residing in the despicable body. We must dwell upon this idea at some length.

In a popular vacana attributed to Basava, a distinction is made between the body and the temple. We are told that things standing (sthāvara) will fall apart, while the moving ones (jangama) will not. ${ }^{234}$ It might appear that the vacana is expressly making a case for the body. This, however, is not the case. While it is not hard to find more such vacanas from a corpus exceeding 20,000, they add up in the narrativized anthologies to produce a cumulative picture of the body as undesirable. There are numerous instances where this is explicitly stated. Cripple me, blind me, deafen me, and place me at the feet of your śaranas, says another vacana attributed to Basava. ${ }^{235}$ Elsewhere in the corpus, we are told to worship the lord before age, grey, and death takes us. ${ }^{236}$ More ruthless is the treatment of the body in the vacanas attributed to Akka Mahādēvi. The body is dirt, we are told, ${ }^{237}$ and after it has known the Lord, who cares if the body feeds a dog or soaks up water? ${ }^{238}$ All that perhaps matters is a prayer: O Cennamallikārjunā, don’t say those you love have a body. ${ }^{239}$

Cāmarasa tries to offer a reasonable-sounding critique of the body. In the conversation between Gōrakșa and Allama, the latter says, "If kāya (the body) is strengthened, then māy $\bar{a}$ (illusion) is strengthened; if $m \bar{a} y \bar{a}$ is strengthens, then chhāya

234 See Ramanujan 1973: 70 (No. 820) for the most popular translation of this vacana. Also see the discussion of this vacana (pp. 1-4), which is however marked by formalist over-reading.

235 Ibid., no. 59, p. 52.

236 Ibid., no. 161, p. 60.

237 Ibid., no. 12, p. 98.

238 Ibid., no. 117, p. 109.

239 Ibid., no. 157, p. 113. 
(shadow, i.e. the unreal) is strengthened; there is no accomplishment (siddhatana) if $k \bar{a} y a, m \bar{a} y \bar{a}$, and chhāya are strengthened." ${ }^{240}$ Gōrakșa was the progenitor of a system that believed in kāyasiddhi. The primacy this system gave the body, drew from the idea that the body and the self were identical, and that the only way to overcome suffering was to strengthen the body and make it hard like a diamond (vajrakāya). The Nāthas developed yogic practices with this goal in mind. It is this worldview that Allama challenges in the Prabhulingalīle. His response to Gōrakșa's declaration that "I am the body" 241 is in the form of a time-tested trope: "can the fool, who considers the dirty loathsome body that is a sewer of bone, skin, shit, piss, and blood, know the self?" 242 The conversation between the two giants does not resolve the matter. There is a final round of physical confrontation. Gōrakșa insists Allama to strike him with a dagger. Allama accepts it reluctantly, and strikes Gōrakșa hard. The dagger hits Gōrakșa with a 'khanil' sound. The earth shakes, the mountains tremble to cast boulders, but not a hair of Gōrakșa's is cut off. Amazing indeed is Gōrakșa’s diamond body (vajrapiṇaśarīra). But Allama is not impressed. "Will the accomplished one's body make a 'khaṇil' sound?”, he asks. Gōraḳsa is taken aback by Allama’s response. If attaining a diamond body is not accomplishment, what is? Strike me, and learn for yourself, replies Allama. Gōrakșa strikes him. The dagger passes through Allama's body as if passing through empty space. Allama remains unhurt. Gōrakșa realizes that real accomplishment lies in transforming the body into a void (bayalu or śūnya), not in making it hard like a diamond. ${ }^{243}$

Nijaguṇa Śivayōgi (ca. 1500), while endorsing the wretchedness of the body, makes another interesting argument in the Paramānubhavabōdhe. According to him, sometimes I say that "I am the body", and at other times that "the body is mine". The latter implies possession, and we can possess only things external to us; on the other hand, the former does not suggest possession, but unity instead. Surely then, there is some confusion here about the status of the body, which, Nijaguna argues, is reason enough to reject the body. ${ }^{244}$

Discussions concerning the body are elaborate in the Sūnyasampādane tradition. Halageyārya's version of the text may be examined as an example. Here, Siddharāma is represented as a believer in prānalinga. According to this position, the body was the pițha (platform) hosting the prāna (breath), which was the linga. What then was the need for an external object or symbol (kuruhu)? Allama on the other hand swore by iștalinga, i.e., an external object of one's choice, representing the linga. The iștalinga

240 Prabhulingalīle, 19.37.

241 Ibid., 19.21.

242 Ibid., 19.22.

243 Ibid., 19.25-35.

244 Paramānubhavabōdhe 3.3.2. See 3.1-8 for an extensive argument. Also see Devadevan 2009b for a critique of this argument. 
was to be placed on one's palm (karasthala) and worshipped constantly. The emphasis was on the togetherness (sanga) of the body (anga) and the linga, and not their unity. Allama held that the inner (antaranga) and the outer (bahirainga) complemented one another. And so did the tangible (iștalinga) and the intangible (prānalinga), and the real and its symbol. One had to transcend the symbolic, but this was to be done by holding on to the symbolic. ${ }^{245}$ It is for this reason, perhaps, that Halageyārya's Allama speaks not of the dissolution of the body (dēha), but the dissolution of bodyconsciousness (dēhabhāva). ${ }^{246}$ Like most of his contemporaries, Halageyārya framed his thought in terms of binaries, but it sprang from deep reflections, and was marked by a profound measure of ideational integrity. It is thus that he is unable to imagine the unmanifest without imagining the manifest, just as light is impossible without darkness, and truth unthinkable without untruth.

In his Anubhavāmrta (ca. 1675), Mahalingaranga made his rejection of the body more explicit. Bones, nerves, and marrow are born of father's filth, mother's blood turns into blood, flesh and skin, the distinction between man and woman is merely of form, the body is not the self, but only a moving pot of shit. ${ }^{247}$ Father's filth ripens in the mother's womb that discharges filthy blood month after month to produce a filthy body that is not the self. ${ }^{248}$ Ranga also dismisses the view that the breath (prāna) is the self. ${ }^{249}$ What the Anubhavāmrta introduces to us is a sublime self that is incorruptible in spite of its earthly associations. The eighteenth century saint Cidānanda Avadhūta goes to the extent of saying that the long association which the self has had with the body has made it as woe-begotten as the latter, but it remains omnipotent enough to retain its resilience and inhibit the body's waywardness. ${ }^{250}$ The self may inhabit the body and deliberate through the filth and refuse of the material world, but it retains an indestructible core whose essence is too pristine to suffer wounds and scars on account of its engagements with the profane world.

The emphasis of the above discussion was on the rejection of the body that was widely advocated during and after the fifteenth century in the Deccan region. We must not, however, regard this as springing from a deep desire to see the body dissolve into the unmanifest. Such elaborate reflections on the body point to the centrality the body had in the emerging systems of thought, a fascination that brought the body to this central position, and a reification of this fascination in the

245 Sūnyasamppādane of Halageyārya, 252-260.

246 Ibid., 190. In Gūḷuru Siddhavīraṇṇoḍeya’s version, Allama says, without the manifestation of arivu (knowledge), kuruhu will not be eliminated (Śūnyasampādane of Gūlūuru Siddhavīraṇnoḍeya, 3.106). In Halageyārya's version it is marahu (forgetfulness) that is said to remain as long as arivu in not manifest.

247 Anubhavāmṛta, 3.37.

248 Ibid., 3.38.

249 Ibid., 3. 40-43.

250 Jñ̄̄nasindhu 27.23-45. 
form of intellectual reflections. That it was the warmth of the body that was desired, and not its disavowal, is underlined by the parapraxis contained in these works. For wasn't Akkamahādēvi on the look out for a guru who could teach her how to unite with Siva without the dissolution of the body? ${ }^{251}$ The body is the ultimate form of possession. Owning a body differs fundamentally from owing a house, possessing a piece of land or acquiring an object of desire. For, unlike these, the body is not merely a source but also the destination of desire. Libidinal experience can have its source in an object external to the body, but the experience itself is sensory, and therefore, primarily a bodily experience. And so is accomplishment. It has to be sensed. Maurice Merleau-Ponty was perhaps right when he identified the body as "the mirror of our being". ${ }^{252}$ Small wonder then that Allama Prabhu, in another instance of parapraxis, asks Gōrakșa who it is that attains siddhi after the body is destroyed. ${ }^{253}$

It is tempting to prolong this discussion concerning the body. The sources on hand offer rich material for this discussion. But our present purpose has already been served. The rejection of the body was not a rejection. It was the ruse of a new self that longed for a body.

The tradition of reflecting upon the body, inaugurated by the višiștādvaita school, found fertile expression among the Saivas of Karnataka. So did the other two categories: guru and lìlâ. We have noticed earlier that the guru was the first of the eight armours identified by the Viraśaivas. The revered guru was the only valid source of knowledge for an aspirant. He or she imparted knowledge, and dispelled the darkness of ignorance. This, however, was not in the form of instructions given in a monastery to a mute and submissive student. For, the recipient of knowledge was a future teacher, and had to be recognized for all practical reasons as an incipient guru. The emphasis, therefore, was on imparting knowledge in a dialogic context. And exemplifying this process of knowledge transmission was Basava's anubhava manțapa, where Allama arrived and engaged in long debates with other śaranas who accepted him as their teacher. The four extent Sünyasampādanes embody this mode of representing the guru.

The idea of lìlā also had a tremendous appeal to the Saivas. But they did not restrict its scope to representing the world as a play of the supreme, but expanded it to incorporate the acts of the śaranas, which were also regarded as lìlā. Kallumaṭada Prabhudēva's work was befittingly called the Lingalīlāvilāsacāritra. Here, he described creation as follows:

thus, the undivided, sphere-shaped, great embodiment of luminance, the Mahālinga, was divided into the linga and the ariga, as it worshipped itself and performed püja in the sport of

\footnotetext{
251 "What great teacher have I today, from whom the way of uniting with Siva without the dissolution of the body can be gained?” Prabhulingalile, 10.30. (Translation mine).

252 Merleau-Ponty 1962: 171.

253 Prabhulingalīle, 19.26.
} 
līlā. Thus was it divided into two: the Mahālinga gained five faces and became the Lingamūrti known as the five-faced. When a part of the effective power of luminance of the dynamism of the consciousness that illuminates the Lingamūrti was separated, it became the ariga called ätma. The Lingamūrti's place was told in both the linga and the ariga thus formed.

līlayā sahitah sākṣādumāpatiritīitīā

lìlayā rahitaḥ paścāt svayaṃbhuriti kathyatē

When the Mahāghanalinga is lìlā, he is called Umāpati. When līlā ceases, he becomes Svayambhu (self-born). This is the meaning of this text. ${ }^{254}$

Creation, for Kallumathada Prabhudēva, was a divine sport, as it was for the proponents of višiștâdvaita. But as opposed to the viśiștâdvaitis, the acts of the saints also were represented as lìlā in the Vīraśaiva works. Every act of Allama was regarded a lìlā played by him, and his hagiography by Cāmarasa aptly called Prabhulingalīle. Accounts on the life of the saints could therefore incorporate supernatural acts like miracles and magic. The representation of the acts of the sarana as lilla was governed by the idea that the śaraṇas were members of Śiva's entourage (śivagana) who had incarnated on earth to carry out a predestined mission, or play. The poet Bhima considered even killing Jaina saints, breaking up their heads, and the destruction of Jaina shrines by the Viraśaivas as acts of lì $\bar{a}^{255}$

By the sixteenth century, mundane acts of devotees were also being referred to as lìlā. Thus, in Sāantalingadēśikan's Bhairavēśvara Kāvyada Kathāmaṇisūtra Ratnākara, Annadānēśvara is said to have obtained the throne of Nīlagunda through lìla..$^{256}$ Devotees of Śiva live in līlā, says Gubbiya Mallaṇārya in his Vīraśaivāmrtapurāṇa, and those who insult such devotees will fall into the great abyss of hell, upside down. ${ }^{257}$

We must now turn to one final aspect of the great Vijayanagara project. This was by any reckoning the most influential outcome of the initiatives of Mahalingadēva and his peers. Strange as it may seem, the tradition it invented has not yet been fully acknowledged as an invented tradition by modern day historiography. Historians of our times have for some reason not extended their gift of skepticism to bear upon this invented tradition. The result is that the myth of Kalyāna, Basava, the anubhava mantapa, and a great twelfth-century revolution has lingered on in the academic repertoire as well as in the popular imagination.

The city of Kalyāna rose to prominence in the early eleventh century. It seems to have had humble beginnings in the late tenth century as an important stopover on a trade route. It was an unpleasant city in terms of its geography. There were no rivers nearby, the Bhīma and the Kārañja being many miles away from the city. The

254 Lingalìlāvilāsacāritra, 3.7. (Translation mine).

255 Basavapurāṇa, 50.72-73.

256 Bhairavēśvara Kāvyada Kathāmaṇisūtra Ratnākara, 1.9.

257 Vìraśaivāmrrtapurāṇa, 3.10.51. 
land was dry, but capable of throwing up a substantial surplus if properly irrigated, but the region was not topologically conducive for building lake networks like those in southern Karnataka or the Kāvēri delta. Agriculture tended to be rain-fed. In the neighbourhood of Kalyāṇa was the village of Mayūrakhiṇụi (Mōrkhaṇdi), which resembled Kalyāṇa in its topography. The Rāșțrakūṭas had ruled from here for a while in the eighth century but moved to Mānyakhẹța (Mālakhēḍa) in the ninth century. For some reason, the Cālukyas, who overthrew the Rāșțrakūṭas in ca. 973 and established themselves at Mānyakhēța, moved to the old base of the Rāṣṭakūṭas over half a century later. Kalyāna became their new headquarters. They ruled from here for a century and a half in the eleventh and the twelfth centuries.

The Cālukyas transformed Kalyāna into a great city and built a fort at a strategic location. The Tripurāntaka temple (which has not survived) was a major landmark of the city. Kalyāṇa hosted Vijñānēśvara, the great lawgiver of the Mitākșara fame. And here in the court of Vikramāditya VI lived Bilhaṇa from Kashmir, who wrote in honour of his patron one of the most celebrated work in Sanskrit: the Vikramānkadēvacarita. ${ }^{258}$ To him is also attributed the Caura Pañcāsika. Kalyāna is also likely to have been the place where the Cālukya king Sōmēśvara III wrote the Mānasōllāsa.

By the late twelfth century, the high noon of the city's prosperity had come to pass. Its importance declined after the Kalacūri chief Bijjala II usurped the throne in 1162. Bijjaḷ II and his son ruled from their headquarters Mangalavāḍa, and had Kalyāṇa as one of their outposts (nelevị̄u). The rebel Kaḷacūri claimant Kannara (Karṇa) tried to establish himself at Kalyāna. Bijjala II had appointed Basava, the nephew of one of his functionaries Baladēva, as his treasurer, and had given his (adopted?) sister Nīlāṃbike in marriage to him. Basava was a devout Śaiva who was born in a brāhmaṇa family at Bāgēvāḍii (now Basavana Bāgēvāḍi). As a young boy, he had rebelled against orthodox brāhmana practices and torn away his sacred thread. He stayed for a while at Kūdalasanggama where the Kṛ̣ṇa meets the Malaprabha, and studied under a Śaiva teacher. During his stay at Mañgalavāḍa as Bijjaḷa II’s treasurer, he organized feeding (dāsōha) for wandering Śaiva saints, the Jangamas. A number of Jangamas reached Mañgalavāạa to obtain his patronage. Among them was Allama Prabhu, a drummerturned-saint from the city of Balligāve. The feeding was organized with abject disregard for prevailing caste norms. Basava seems to have spent a large amount of money on feeding. Charges were levelled against him of misappropriating funds from the royal treasury. He was also accused of violating norms of commensality, as he had partaken food from the house of a low caste devotee of Śiva called Saṃbhōli Nāgayya. His relationship with Bijjala II deteriorated. Bijjala II was killed in 1167 by a certain Jagadēva who appears to have been a henchman of Sōmēśvara IV, the surviving scion of the erstwhile Cạlukyas. In the confusion that led to the killing of Bijjala II, Basava left Mangalavāḍa, and met his end at Kūḍalasangama under mysterious

258 On the Vikramāinkadēvacarita, see Bronner 2010. 
circumstances. Kalacūri rule ended in 1184, and Sōmēśvara IV returned to power. His rule ended in ca. 1199. With this, the history of the Cālukyas came to an end. Kalyāna also ceased to be the nerve centre of the region's political and economic life.

Harihara's Basavarājadevvara Ragale (ca. 1175) is the first hagiographic account on the life of Basava. In this work, Basava is found to be active in Mangalavāḍa. This is hardly surprising. Among the twelfth-century śaraṇas, only some, such as Maḍivāḷa Mācayya, Bāhūru Bommayya, and Telugu Jommayya are known to have lived in Kalyāna. What is of interest, though, is the fact that apart from Basava's nephew Cannabasava, Allama Prabhu is the only major contemporary śarana from among the composers of vacanas, whom Basava is said to have ever met. In Harihara's accounts, there are no allusions to his meeting with Akkamahādēvi, Siddharāma, Maḍivāḷa Mācayya, and the other important śaranas. Harihara is also silent on the existence of the anubhava mantapa, the hall of experience, where the śaranas are believed to have met in order to discuss a wide range of issues from the sublimity of the spiritual world to the waywardness of everyday life.

An important change occurred in the hagiographic accounts, when in Pālkurike Sōmanātha's Basavapurāṇamu, some of the śaraṇas met with Basava. More importantly, the scene of action shifted to Kalyāna. Sōmanātha was evidently relying on stories that circulated among the believers in centres of pilgrimage like Śrîsailam. Inasmuch as Bijjaḷa II had killed the Cālukya king of Kalyāṇa and seized his throne, it was not difficult to imagine the activities of his treasurer Basava in that city. Given the symbolic significance of the city, Bijjala II might have wished to bring Kalyāna under his control. In fact, Harihara's Kēśirāja Daṇnāyakara Ragaḷe identifies Permāḍi (Bijjaḷa II's father) as the ruler of Kalyāṇa, ${ }^{259}$ although we know from history that Permāḍi ruled from Mañgalavāḍa as subordinate to Sōmēśvara III and Jagadēkamalla II, and contracted matrimonial alliance with the family of his masters. The discrepancy, which unwittingly crept into Sōmanātha's account, reached the Kannada world through Bhīma's Basavapurāṇa. Bhīma's work, and the circulation of Sōmanātha's poem in various forms, profoundly informed the project of Mahalingadēva, Sivagaṇaprasādi Mahādēvayya, Jakkaṇa, Lakkạ̣ṇa Daṇḍeśs, and others. These works also formed the basis for most accounts produced in the late fifteenth, the sixteenth, and the seventeenth centuries on the lives of the śaranas.

There were many variants of this story. But there was consensus on its broad outlines. Basava, the treasurer of Bijjala II, was an ardent devotee of Siva, and the brother-in-law of his patron. He organized feeding (dāsōha) for the śaranas, which attracted saranas from as far away as Saurāștra and Kashmir. To further the cause of the śaranas, Basava set up the anubhava manțapa in which śaranas sat down to discuss and debate the nature of the self, the essence of the supreme, and the right practices required for realizing the supreme, and to criticize superstitions, rival

259 Kēśirāja Daṇṇāyakara Ragaḷe, 1.31-32. 
belief systems, and inequalities based on caste and gender. A throne called śūnya simhāsana was created. Allama occupied this throne. The śaranas composed vacanas in large numbers to expound their views and ideals.

The experiment turned out to be fatal, as the non-Saiva orthodoxy forced Bijjala II to punish Basava for violating caste norms. At Bijjala II’s bidding, two śaranas, Haralayya and Madhuvayya, were blinded. This was done to create terror among the śaranas. A great mayhem followed. A devout śaraṇa called Jagadēva was instructed by his peers to take revenge on the king. Accordingly, Jagadēva killed Bijjala II. Basava left Kalyāna, and became one with the linga (lingaikya) by drowning in the waters at the confluence of the Kụṣna and the Malaprabha in Kūḍalasangama.

This was the story promoted through the works of Pālkurike Sōmanātha and Bhìma. That the scene of action in these works was Kalyāna formed the basis for most works produced as part of the Vijayanagara project under Jakkaṇa and Lakkaṇna Daṇ̣̂ēsa, in which Kalyāṇa became a metonymy of sorts. In the course of time, the story underwent further changes. A reason was invented for the blinding of Haralayya and Madhuvayya. The former was a Mādiga (tanner) and the latter a Brāhmaṇa, the new story contended. Under Basava's influence, the Brāhmaṇa had given his daughter in marriage to the Mādiga's son, a pratilōma marriage that shocked the orthodoxy, and forced Bijjala II to mete out the punishment on Haralayya and Madhuvayya.

Unfortunately, it is this version that is passed off as history in most modern accounts. ${ }^{260}$ Expressions like Kalyāna-krānti (the revolution of Kalyāṇa), Basavakrānti (the Basava revolution), Śaraṇa-caluvaḷi (the śaraṇa movement), and Vacana-caluvali (the vacana movement) evokes passionate responses from the Kannada vernacular academia, bordering on the fanatic. ${ }^{261}$ Not only has this story of revolution enamoured hundreds of Grade C researchers, it has passed muster with such thoughtful scholars as D.R. Nagaraj, M.M. Kalburgi, and A.K. Ramanujan. The academic, literary, and popular works produced on Basava, his revolution, and its spillovers (including anthologies of vacanas, and critical and popular editions of Viraśaiva literature) run into over a million printed pages. What is missed in the process is a fascinating history of the making of the myth of Kalyāna, and how the myth became a driving force behind several systems of renunciation in the region after the fifteenth century. ${ }^{262}$

260 Instances are too many to be listed out. But see Desai 1968 and Chidanandamurthy 2007 for a general history. Also see Ramanujan 1973; Schouten 1995; Ramaswamy 1996; and related essays in Kalburgi 2010.

261 See Devadevan 2009: 90-96, for a critique of this position.

262 Devadevan 2007. 